\title{
Prioritizing Watershed Restoration, Management, and Development Based on Geo-Morphometric Analysis in Asir Region of Saudi Arabia Using Geospatial Technology
}

\author{
Javed Mallick*, Vikash Shivhare², Chander Kumar Singh ${ }^{3}$, Majed Al Subih ${ }^{4}$ \\ ${ }^{1}$ Department of Civil Engineering, College of Engineering, King Khalid University, Abha, Kingdom of Saudi Arabia \\ ${ }^{2}$ Department of Data Science and Engineering, Quantela Inc. Bengaluru, India \\ ${ }^{3}$ Department of Energy and Environment, TERI School of Advanced Studies, New Delhi, India \\ ${ }^{4}$ Department of Civil Engineering, College of Engineering, King Khalid University, Abha, Kingdom of Saudi Arabia
}

Received: 3 June 2021

Accepted: 11 September 2021

\begin{abstract}
The groundwater resource in the Kingdom of Saudi Arabia is a non-renewable resource. Geographical information system and remote sensing are proven to be an efficient tool for locating water harvesting and recharge structures by prioritization of sub-watersheds through morphometric analysis. In this study, the watershed prioritization in Asir Province has been assessed by linear, aerial, and relief morphometric parameters. Morphometric analysis has been attempted to prioritize a total of eleven subwatersheds, of which six sub-watersheds in Tathlith Wadi and five sub-watersheds in Bisha Wadi were delineated using digital elevation model (DEM). Advanced space-borne thermal emission and reflection radiometer of $30 \mathrm{~m}$ resolution DEM has used to generate drainage networks and delineation of subwatersheds using ArcGIS software. The important derived morphometric parameters have computed on the base of already developed mathematical formulae and methods. A novel and quantitative approach based on the compound parameter by using linear and shape parameters of the respective sub-watershed was attempted for its prioritization. The total area of sub-watershed in Wadi Bisha, which lies under high, medium, and low priority is approximately $40 \%, 20 \%$ and $40 \%$ respectively. whereas in Wadi Tathlith, the area under high and medium priority is $67 \%$ and $33 \%$. The watersheds BSW2 and BSW4 in Wadi Bisha and TSW1, TSW2, TSW3, and TSW5 in Wadi Tathlith would require immediate intervention and efficient action plan for water and soil conservation. The interrelationship between the various morphometric factors of the basin has been studied using a correlation matrix. Further, morphometric factors have been studied in relation to the sub-basins to understand the existing relation between the factors and the sub-basins. The prioritized watersheds were validated using the
\end{abstract}

e-mail: jmallick@kku.edu.sa 
water yield data from borewells in the respective watersheds. All high prioritized watersheds but one in Wadi Tathlith (TSW3) showed poor water yield. Prioritized sub-watersheds require immediate soil $\&$ water conservation initiative according to the given rank to ensure efficient watershed planning and management and improving the potential of water resources under sustainable watershed management and development in the Asir province of the Kingdom of Saudi Arabia.

Keywords: morphometry, sub-watershed, prioritization, Asir Province, GIS

\section{Introduction}

A catchment or a watershed is a natural hydrological unit which permits surface runoff to a defined drainage network and allows its exit at a particular point. Watershed management is the process that involves adjustment in the natural system of watershed to achieve specific objectives. The watershed development spins over the conservation of soil and water resources in the watershed and hence, it is imperative to prioritize the watersheds based on needs for conservation and development. The Kingdom of Saudi Arabia (KSA) has recently focused on interventions to resolve the problem of water resources required for domestic, agriculture, and industrial consumption. Interventions such as building of check dams to increase water recharge and more costlier interventions such as desalination of sea water in coastal areas have been focus of the policy makers in the region [1]. Arid climate coupled with low rainfall, increased agricultural activity and extensive water use in industrial/domestic pursuits has aggravated the problem of already water-scarce regions [2-7]. Furthermore, the govt. of KSA has launched schemes to search for new aquifers in the desert areas and accordingly started interventions to conserve soil and water resources in the region.

A watershed is a complex system within which several physical components and processes interact with each other. A watershed consists spatially variable topography and therefore variable response to the physical processes taking place within it. The hydrological pattern of the catchment is mainly controlled by the morphometric characters of the drainage which are in turn influenced by climate, infiltration capacity of rock and soil, and terrain characteristics and can be easily determined using remote and GIS (geographical information systems) techniques [8-13]

Geomorphological parameters impact the entire watershed parameters thus influencing watershed characteristics such as runoff and sediment loss [14-17] . However, due to lack of hydrological measurements in most of the watersheds, the morphometric parameters along with other satellite data derived information such as land use land cover can be used to develop prioritization of sub-watersheds. Digital Elevation Model (DEM) derived morphometric analysis is highly useful for ungauged or poorly gauged basins as this can provide information for different aspects of the drainage basin. The morphometric analysis is typically performed in an ungauged basin and helps in better planning and management of watershed or basin in the context of the regional hydrological modelling [18]. The morphometric study of a catchment and its drainage network can be well understood by means of physiographical variables viz. slope, drainage network structure, drainage split location, length of stream and relative relief, shape factor, bifurcation ratio, circulatory ratio, and drainage density for catchment prioritization and enactment of conservation initiatives for natural resources [16, 19-21]. Morphometry defines the analysis of the structure of the Earth's surface, shape, and facet of its landforms $[15,16,19,22-$ 25]. The earlier work on deriving the morphometric parameters were based on manual methods and are described in the works of Horton [26, 27], Miller [28], Smith [29], Strahler [30]. The morphometric analysis of drainage basins helps to comprehend aspects of linear, areal, and relief parameters. These parameters have been used by geomorphologists to study runoff, morpho/neotectonics, flash floods [31, 32], soil erosion [33], groundwater potential [34], watershed prioritization [35-38], check dam positioning, etc $[13,39-47]$. Watershed prioritization has become important in identifying and prioritize the regions which would require treatment for water and soil conservations practices. However, several methods have been taken into account for ranking the watersheds such as pearson's correlation [48], composite ranking method, multiple criteria analysis [49], and analytical hierarchical process using Saaty's scale [50-52]).

A major part of the province is water-scarce and is subjected to erosion and other forms of land degradation due to natural and anthropogenic activities. Therefore, there is a growing need to conserve the soil along with sustainable management and development of the water resources. Thus, prioritization of sub-watershed for execution of land and water conservation is essential for preparing a comprehensive strategy for watershed restoration and conservation planning.

With the above background, the study prioritizes the sub-watersheds of the Bisha and Tathlith watershed in the Asir region using a thorough methodological approach to provide insights and help to develop a management plan. Hence this methodology will be helpful to decision makers to study the drainage network within the watershed or river basin and conserve natural resources based on priority. 


\section{Material and Methods}

\section{Study Area}

Asir Province, south-western part of Saudi Arabia has a semi-arid climate with undulating and mountainous terrain. Rapid urbanization and socioeconomic activity put a tremendous amount of pressure on water resources of Saudi Arabia. The region has limited sources of water, which has been aggravated due to irregular precipitation and high temperature. The province consists of two sub-watersheds in Wadi Bisha and Wadi Tathlith. The Bisha sub-watershed covers an area of almost $26680 \mathrm{~km}^{2}$ whereas the Tathlith watershed covers an area of $26298 \mathrm{~km}^{2}$ (Fig. 1). The topography of Asir is sturdy and has mountain peaks which are almost $2990 \mathrm{~m}$ above mean the sea level extending towards the border of Yemen. The province has some of the highest peaks at Jabal Alsouda near Abha. Some small permanent Wadi originated from the higher mountains due to the high amount of rainfall received, but none flows for more than $50 \mathrm{~km}$ before disappearing into the Wadi plains. The KSA consists of pre-cambrian rock strata of igneous and metamorphic origin in the Arabian shield to the recent deposits of sand, silt and clay in the Arabian shelf. The climate of Saudi Arabia is "desertic climate" [52] and the region is designated by well-defined climatic zones due to high spatio-temporal variability. Most part of the country is hot and dry [53] where infrequent precipitation and high temperatures are observed and classified as desert and water deficit condition [54,55] and other side, south-western coast described as semiarid region is surrounded by mountainous topography where irregular heavy rainstorms happen throughout the year $[52,56]$. Due to wet oceanic currents, the region receives rainfall due to south-western monsoon. High temperatures over the peninsula during the summer lead to the development of tropical continental air, which forms part of the monsoon low circulation centered over northwest India. The regions receive the highest amount of rainfall in the entire country during the months of March to June and even flash floods are observed in the downstream areas [57]. The maximum amount of rainfall is received in the month of April with an annual average of $244 \mathrm{~mm}$. The precipitation results from orographic convection over the scarp in the Asir region, especially during the late summer monsoon season. Rainfall exceeding $200 \mathrm{~mm}$ per annum is limited to a $20-30 \mathrm{~km}$ wide crest zone. Consequently, eastward, and northward Wadi flow decreases rapidly downstream, and deposition is greater than erosion near the eastern edge of the plateau. The Wadis broaden in mid-course where runoff from tributaries coalesce, but many are restricted by narrow throats, mainly where metamorphic land from plains is underlain by granites. The low availability of gravel and grit indicates low relief and gentle gradients of the stream at the time of silt deposition. Within last two decade, it has been observed that the Asir Province has

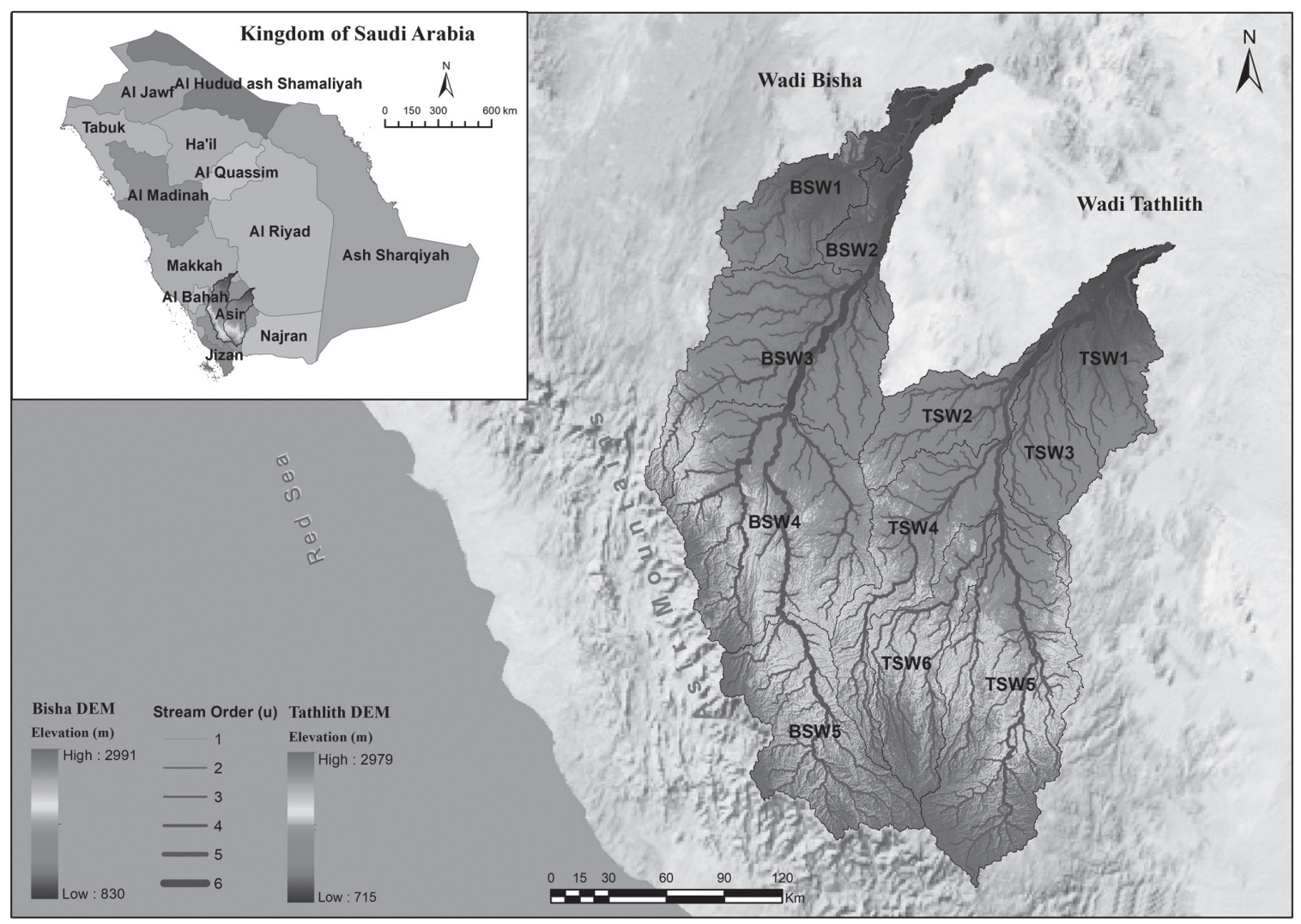

Fig. 1. Study region in Asir province consisting of two major watersheds, Wadi Bisha and Wadi Tathlith. 
a severe problem of soil erosion, affecting the forested land, agriculture productivity, sediment and water quality, due to steep gradient of slope and irregular rainfall pattern [57]. Therefore, Wadi Bisha and Wadi Tathlith watershed which covers most of the part of Asir province have been selected for strategized sub-watershed prioritization, where soil and water conservation measures can be planned for watershed restoration and conservation.

\section{Data Source}

Digital elevation model (DEM) represents the topographical characteristics of the landscape and thus offers insights to understand the watershed configurations. Shuttle Radar Topographic Mission (SRTM) DEM has been procured from the USGS website at $90 \mathrm{~m}$ spatial resolution. SRTM DEM (90 m) is considered more accurate compared to ASTER DEM $(30 \mathrm{~m})$ as radar beam penetrates the tree canopy to get accurate topographic measurement, whereas the ASTER gets the reflection of sun radiations from tree canopy which are photogrammetrically processed to derive DEM. The automated extraction of stream network and watershed map were prepared using pour points with the help of ArcHydro tool in ArcGIS 10.3, which was then cross validated with 1:50,000 scale topographic sheets. The orders for the stream were determined using Strahler's method. A total of 11 subwatersheds were delineated for detailed morphometric analysis and further analyzed for linear, aerial, and relief aspects. The detailed calculation methods adopted for morphometric characteristics are shown in Table 1. A total of 19 morphometric parameters were calculated including basin perimeter, basin length, stream number, stream length, stream length ratio, mean stream length, stream order, bifurcation ratio, mean bifurcation ratio, drainage texture, drainage density, stream frequency, circulatory ratio, elongation ratio, infiltration number, shape factor, relief ratio, basin relief, and roughness number.

\section{Calculation of Morphometric Parameters}

Flow direction and flow accumulation were generated to delineate the watershed and drainage network by defining the threshold value which signifies the level of details of the drainage system. Two major watersheds were delineated, Wadi Tathlith and Wadi Bisha, in Wadi Al Dawasir catchment. Strahler's method was adopted to calculate the stream order network for evaluating the stream segments in the basin. The generated stream order was found in multiple sections of each ordered stream and does not follow the morphometric rule. Therefore, few other intermediary processes were followed to get the actual morphological drainage segments.

For a detailed assessment of morphometric parameters, 6 sub-watersheds (TSW1, TSW2, TSW3,
TSW4, TSW5, TSW6) for Wadi Tathlith watershed and 5 sub-watersheds (BSW1, BSW2, BSW3, BSW4, BSW5) for Wadi Bisha were delineated. The morphometric characteristics for each watershed and sub-watershed which describes the configuration of watershed were calculated. Morphometric parameters were determined and analyzed mathematically and quantitatively in detail for the watersheds of Wadi Tathlith and Wadi Bisha.

Sub-watershed prioritization for Wadi Tathlith and Wadi Bisha was performed for sound hydrological understanding and mechanism of denudation in both the watersheds. The sub-watersheds of both catchments were prioritized based on the compound value, estimated from linear, relief and areal parameter characteristics and prioritized rank were assigned to each sub-watershed.

\section{Sub-Watershed Prioritization}

The compound value $(\mathrm{Cp})$ is derived for each subwatershed of Wadi Tathlith and Wadi Bisha based on morphometric parameters and prioritized for each subwatershed by assigning ranking, where rank 1 indicates high priority and consecutive number represent the decreasing priority of ranking. Prioritization ranking of all sub-watersheds of Asir was carried out based on the compound parameter values. The highest priority/ rank for linear parameters was given based on the highest and lowest values.

\section{Results}

\section{Morphometric Analysis}

The drainage morphometry and sub-watershed prioritization based on the compound value of linear and shape parameters have been computed and analyzed for the Wadi Tatlith and the Wadi Bisha watershed and their respective sub-watersheds, to develop a prioritization of sub-watersheds.

Morphometric parameters for the selected watersheds were computed and analyzed successfully, which defines the watershed characteristics and configurations to understand the structural control, hydrological mechanism, and denudational processes of the watershed.

\section{Linear Parameters}

\section{Stream Order and Stream Number}

The designation of stream order was assigned according to the method of Strahler[30] on a hierarchic ranking of streams. Stream order $(\mathrm{Nu})$ and stream segment numbers are the primary investigations of drainage analysis which is based on Strahler's hierarchical order of the streams. The first-order streams are the smallest tributaries of the watershed, and two 
Table 1. The description of morphometric parameters calculated for the study area.

\begin{tabular}{|c|c|c|c|}
\hline Aspects & Morphometric Parameters & Methods/Formulae & Reference \\
\hline \multirow{9}{*}{ LINEAR } & Stream Order $(U)$ & Drainage Hierarchical Order (Strahler's Law) & Strahler, 1964 \\
\hline & Stream Length $(L u)$ & Length of the Stream & Horton, 1945 \\
\hline & \multirow{2}{*}{ Mean Stream Length (Lsm) } & $\mathrm{Lsm}=\mathrm{LU} / \mathrm{Nu}$; where, $\mathrm{Lu}=$ Stream Length of Order, $\mathrm{U}^{\prime}$ & \multirow{2}{*}{ Horton, 1945} \\
\hline & & $\mathrm{Nu}=$ Total Number of Stream Segments of Order ,U' & \\
\hline & \multirow{2}{*}{ Stream Length Ratio (RI) } & $\mathrm{RI}=\mathrm{Lu} / \mathrm{Lu}-1$; where $\mathrm{Lu}=$ Total Stream Length of Order ,U', Lu- & \multirow{2}{*}{ Horton, 1945} \\
\hline & & $1=$ Stream Length of Next Lower Order. & \\
\hline & \multirow{2}{*}{ Bifurcation Ratio $(R b)$} & $\mathrm{Rb}=\mathrm{Nu} / \mathrm{Nu}+1 ;$ where, $\mathrm{Nu}=$ Total Number of Stream Segment & \multirow{2}{*}{ Schumm, 1956} \\
\hline & & of Order ,u'; $\mathrm{Nu}+1=$ Number of Segment of Next Higher Order & \\
\hline & Rho Coefficient $(\rho)$ & $\rho=\mathrm{R} 1 / \mathrm{Rb}$; where, Ratio of Stream Length and Bifurcation Ratio & Horton, 1945 \\
\hline \multirow{4}{*}{ RELIEF } & Basin Relief (Bh) & $\begin{array}{l}\text { Vertical Distance between the Lowest and Highest Points of } \\
\text { Watershed }\end{array}$ & Schumm, 1956 \\
\hline & Relief Ratio (Rh) & $\mathrm{Rh}=\mathrm{Bh} / \mathrm{Lb}$; where, $\mathrm{Bh}=$ Basin Relief, $\mathrm{Lb}=$ Basin Length & Schumm, 1956 \\
\hline & \multirow{2}{*}{ Ruggedness Number (Rn) } & $\mathrm{Rn}=\mathrm{Bh}^{*} \mathrm{Dd}$ & \multirow{2}{*}{ Schumm, 1956} \\
\hline & & where, $\mathrm{Bh}=$ Basin Relief; Dd=Drainage Density & \\
\hline \multirow{13}{*}{ AREAL } & \multirow{2}{*}{ Drainage Density $(D d)$} & $\mathrm{Dd}=\mathrm{L} / \mathrm{A} ;$ where, & \multirow{2}{*}{ Horton, 1945} \\
\hline & & $\mathrm{L}=$ Total Length of Streams; $\mathrm{A}=$ Area of Watershed & \\
\hline & \multirow{2}{*}{ Stream Frequency $\left(F_{S}\right)$} & Fs $=\mathrm{N} / \mathrm{A} ;$ where & \multirow{2}{*}{ Horton, 1945} \\
\hline & & $\mathrm{N}=$ Total Number of Streams; $\mathrm{A}=$ Area of Watershed & \\
\hline & Texture Ratio $(T)$ & $\begin{array}{l}\mathrm{T}=\mathrm{NU} / \mathrm{P} ; \text { where, } \mathrm{NU}=\text { Total Number of First Order Streams; } \\
\mathrm{P}=\text { Perimeter of Watershed }\end{array}$ & Schumm, 1973 \\
\hline & Form Factor (Rf) & $\mathrm{Rf}=\mathrm{A} /(\mathrm{Lb})^{\wedge} 2 ;$ where, $\mathrm{A}=$ Area of Watershed, $\mathrm{Lb}=$ Basin Length & Horton, 1932 \\
\hline & Circulatory Ratio $(R c)$ & $\begin{array}{c}\mathrm{Rc}=4 \pi \mathrm{A} / \mathrm{P}^{\wedge} 2 ; \text { where, } \mathrm{A}=\text { Area of Watershed, } \pi=3.14, \mathrm{P}=\text { Perimeter of } \\
\text { Watershed }\end{array}$ & Miller, 1953 \\
\hline & \multirow{2}{*}{ Elongation Ratio (Re) } & $\mathrm{Re}=2 \sqrt{ }(\mathrm{A} / \pi) / \mathrm{Lb} ;$ where, $\mathrm{A}=$ Area of Watershed, $\pi=3.14$ & \multirow{2}{*}{ Schumm, 1956} \\
\hline & & $\mathrm{Lb}=$ Basin Length & \\
\hline & $\begin{array}{l}\text { Length of Overland Flow } \\
\text { (Lof) }\end{array}$ & Lof $=1 / 2 \mathrm{Dd}$ where, $\mathrm{Dd}=$ Drainage Density & Horton, 1945 \\
\hline & $\begin{array}{l}\text { Constant Channel } \\
\text { Maintenance }(C)\end{array}$ & $\mathrm{C}=1 / \mathrm{Dd}$ where, $\mathrm{Dd}=$ Drainage Density & Horton, 1945 \\
\hline & Infiltration Number (If) & If $=\mathrm{Dd} \times \mathrm{Fs}$ Where, $\mathrm{Dd}=$ Drainage density and Fs=Stream frequency & Umrikar, 2016 \\
\hline & $\begin{array}{l}\text { Compactness coefficient } \\
(C c)\end{array}$ & $\begin{array}{c}\mathrm{Cc}=0.2821 \times \mathrm{P} / \mathrm{A}^{\wedge} 0.5, \mathrm{P}=\text { Perimeter of the basin, } \mathrm{A}=\text { Area of the } \\
\text { basin. }\end{array}$ & Horton, 1945 \\
\hline
\end{tabular}

$1^{\text {st }}$ order stream joins together and $\mathrm{s}$ form next higher order stream. A stream marked as the highest order is associated with greater discharge [30]. This formulation is based on certain characteristics such as basin size, shape, and relief feature of the basin/watershed. Stream order of maximum $6^{\text {th }}$ order was identified in both the watersheds. Wadi Tathlith comprised of 1071 total number of stream segments out of which $78.38 \%$ (839) is $1^{\text {st }}$ order, $16.71 \%(179)$ is $2^{\text {nd }}$ order, $3.82 \%(41)$ is $3^{\text {rd }}$ order, $0.84 \%$ (9) is $4^{\text {th }}$ order, $0.18 \%$ (2) and $0.09 \%$ (1) are $5^{\text {th }}$ and $6^{\text {th }}$ order respectively. Wadi Bisha has 1215 number of stream segments of which $78.11 \%(949)$ is $1^{\text {st }}$ order, $17.12 \%$ (208) is $2^{\text {nd }}$ order and $3.70 \%(45), 0.74 \%$
(9), $0.25 \%(3), 0.08 \%$ (1) are $3^{\text {rd }}, 4^{\text {th }}, 5^{\text {th }}$, and $6^{\text {th }}$ order respectively (Table 2 and Table 3 ).

\section{Stream Length}

The stream length ( $\mathrm{Lu}$ ) of each order segment is calculated by Horton's law [63] for the watershed. Lu represents the development of consecutive stages of drainage segments and reciprocates to the surface runoff of the watershed [61-65]. Stream length is higher in $1^{\text {st }}$ order streams and decreases with higher-order streams, representing the lithological inconsistency and control over geological and morphological characteristics 
of the catchment. The total stream length calculated for Wadi Tathlith is $8759 \mathrm{~km}$ and $8474 \mathrm{~km}$ for the Wadi Bisha watershed. It was observed from the analysis that $75 \%$ of total stream length accounted for $1^{\text {st }}$ and $2^{\text {nd }}$ order streams and only $25 \%$ of total stream length form remaining stream orders $\left(3^{\text {rd }}, 4^{\text {th }}, 5^{\text {th }}\right.$, and $\left.6^{\text {th }}\right)$ for the watershed. The stream length of all the stream order segment is presented in Table 2. Fig. 2 shows that the consistency in the length of the stream around the watersheds demonstrating geological formation and morphological adjustments. Total stream length for all stream orders for individual sub-watersheds was analyzed and it was found that the total stream length is higher $(>2000 \mathrm{~km})$ for the sub-watersheds TSW5, BSW3, and BSW4. The sub-watersheds with total stream length of $>1000 \mathrm{~km}$ is TSW1, TSW4, TSW6, BSW1, and BSW5 whereas the remaining subwatersheds TSW2, TSW3, and BSW2 the total stream length ranges from $500-1000 \mathrm{~km}$ with the lowest for sub-watershed BSW2 of about $587 \mathrm{~km}$ (Table 4 and Table 5).

\section{Mean Stream Length}

Mean stream length (Lsm) is a function of the total length of stream segment by the total number of stream segments in each order [30]. It is observed that low mean stream length (Lsm) increases with increasing stream order, due to slope and variation in topography (Table 2). Low mean stream length in the upper catchment of watersheds indicates the potential of high erosion and young morphological development and is related to mean annual runoff.

Morphometric parameters for individual subwatersheds also were analyzed and observed that mean stream length for all the sub-watersheds in the study are ranging from a minimum of 6.68 (BSW4) to a maximum of 9.01 (TSW1, TSW3). The mean stream length is relatively higher $(>8.5)$ for the sub-watersheds TSW1, TSW3, TSW6, BSW2, and lesser in BSW1, 3, and 4 (Table 5).

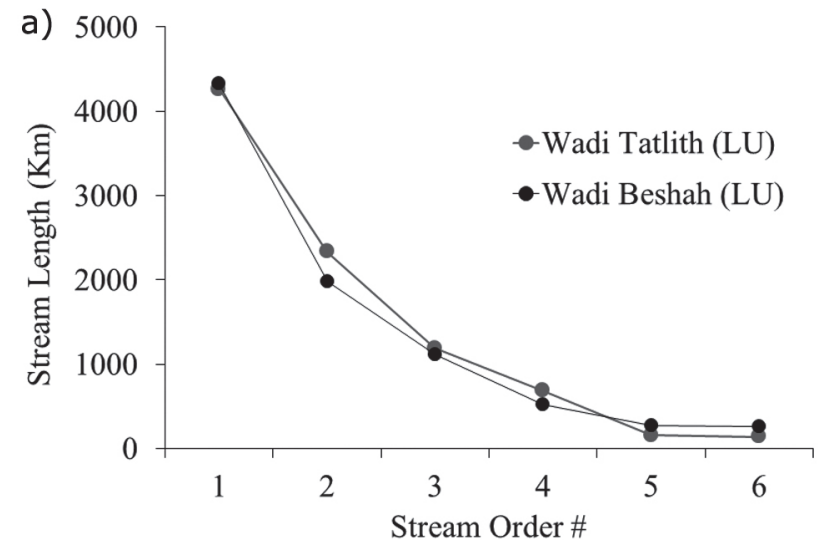

\section{Stream Length Ratio}

Stream length ratio $(\mathrm{Rl})$ represents the higher order of stream length divided by segments of the next lower order streams [63]. Stream length ratio has a strong bearing on the basin's surface flow, discharge and erosion features [69]. Various studies suggest that the ratio between successive stream order changes due to differences in topography and slope, which indicate the important relationship with flow discharge and erosional stage of the basin [66, 67,70]. Stream length ratio ratio values indicate substantial control of surface flow/discharge and erosional features of the catchment. In Table 2, the Stream length ratiovalue is higher in the $1^{\text {st }}$ and $3^{\text {rd }}$ stream order and lower in the $2^{\text {nd }}, 4^{\text {th }}, 5^{\text {th, }}$ and $6^{\text {th }}$ stream order in the Tathlith watershed compared the Bisha watershed. The higher value of stream length ration in most of the stream order in Bisha signifies geomorphic development. Thus, Bisha watershed has low water regime than Wadi Tathlith thus representing higher geomorphic control in the watershed.

\section{Bifurcation Ratio}

Bifurcation ratio $(\mathrm{Rb})$ is an important linear aspect of morphometry, indicating the carrying capacity of water and the potential of occurrence of flood in the catchment. It expresses the ratio between the number of stream segments in the given order to the next higher order stream segments [71]. The bifurcation ratio mainly depends on the physiography, slope of the terrain, and climatic conditions. The mean bifurcation ratio characteristically ranges between 3.0 to 5.0 for a basin when the influence of geological structure on the drainage network is negligible [58, 72]. The analysis showed that the bifurcation ratio in both the selected watershed ranges from 2 to 5 with the mean value of 4.02 for Tathlith and 4.04 for Bisha watershed, respectively. The relatively lower mean bifurcation ratio value reflects the basin's geological variability, greater permeability, and less structural stability [73].

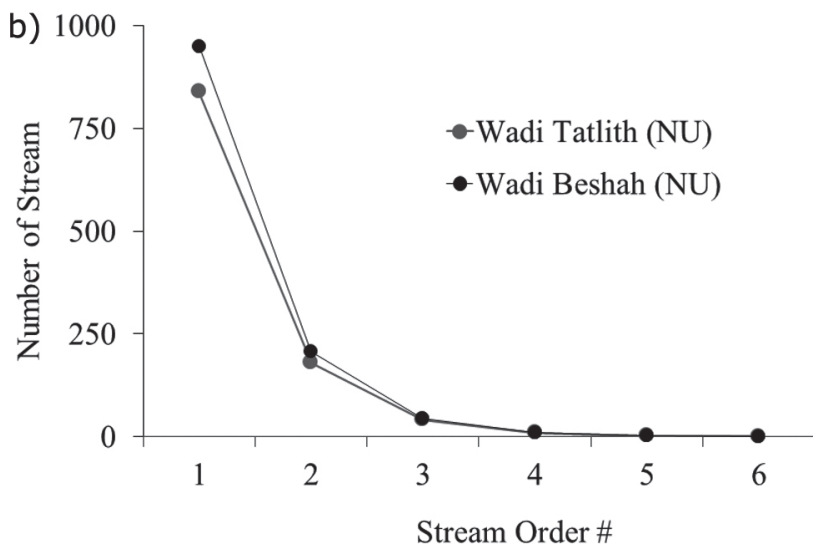

Fig. 2. Relationship between a) stream order against number of streams in each order, b) stream order against stream length of each order for Wadi Tatlith and Beshah respectively. 
The higher bifurcation ratio can be observed in the different order of streams, which signifies the large amount of water received in the upper reaches and the low bifurcation ratio value indicates increased water pressure in the lower reaches (Table 2). In this study, it is observed that the mean bifurcation ratio is higher $(>4)$ in sub-watersheds TSW3, TSW6, and BSW1, BSW3 suggesting these sub-watersheds relatively shows the presence of a rock with high slope and low permeability. On the other side, sub-watersheds TSW1, TSW2, TSW4, BSW2, BSW4, and BSW5 shows low structural control and high permeability.

\section{Areal Parameters \\ Area and Perimeter}

Area (A) and perimeter $(\mathrm{P})$ are important parameters and have been calculated for both the watersheds. Wadi Tathlith watershed covers $26,298 \mathrm{~km}^{2}$ area with a perimeter of $1501.92 \mathrm{~km}$ whereas Wadi Bisha covers $26,680 \mathrm{~km}^{2}$ area with a perimeter of $1824 \mathrm{~km}$, which indicates the total length of watershed boundary and watershed area directly affect the generated runoff and it shows a strong relationship with average annual runoff.

\section{Drainage Density}

Drainage density (Dd) is a vital parameter of landform which represents the density or closeness of the stream network and accommodates a quantitative measurement of potential runoff and dissected landscape. It expresses the ratio of the total length of stream irrespective of stream order to the per unit area of the basin [63]. Rock type, infiltration capacity, surface roughness, climate, relief, vegetation cover, and runoff intensity are factors that directly affects the drainage density (Dd) [64, 65, 77]. Drainage density (Dd) for Wadi Tathlith watershed is $0.33 \mathrm{~km} / \mathrm{km}^{2}$ whereas it is $0.32 \mathrm{~km} / \mathrm{km}^{2}$ for the Wadi Bisha watershed, suggesting low drainage density in the watersheds. This is due to low relief, low slope, high infiltration capacity, and low water regime throughout the watershed. The drainage density value was estimated for different watersheds of the study area (Table 5). It is observed from the analysis that drainage density values vary from a minimum of 0.07 (BSW3) to a maximum of 0.36 (TSW3) and 0.37 (BSW2). The drainage density was found to be very low in BSW3 and BSW4.. It is observed in the study that drainage density is low in both the watershed, and infiltration and sub-surface flow are dominant in the watersheds.

\section{Texture Ratio}

Texture ratio $(\mathrm{T})$ is determined by the total number of streams of first-order divided by the perimeter of the watershed [71]. It is related to the relief, lithology,

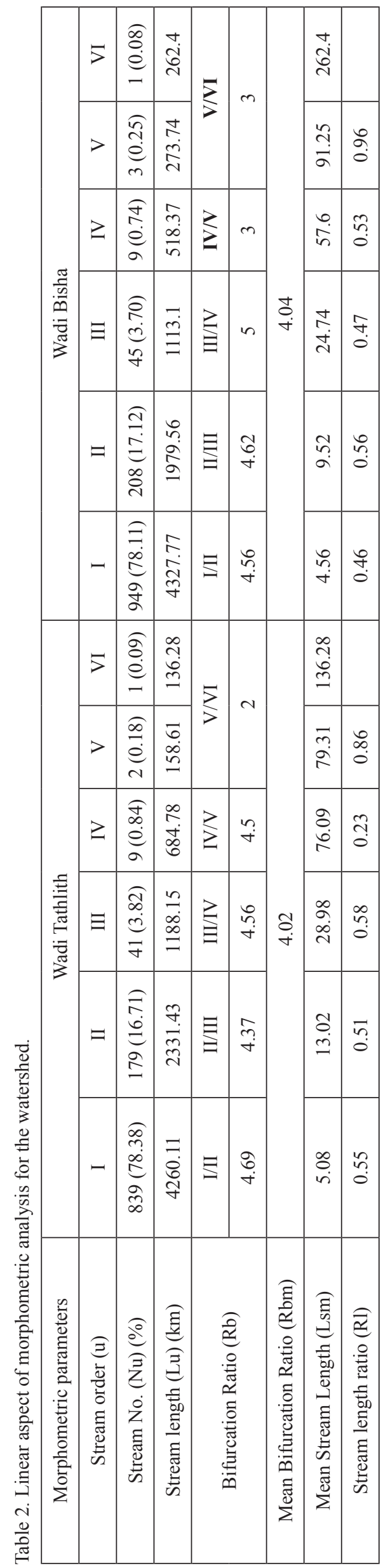


and infiltration capacity of the watershed. The texture ratio of Wadi Tathlith watershed is found to be 0.56 whereas it is 0.52 for Wadi Bisha watershed. The computed value is found to be very low suggesting very coarse texture and reveals that watersheds have very low rainfall, high infiltration rate, and low relief. It was noted from the study that the value of texture ratio (Table 5) was found to be very low in all the subwatersheds of Wadi Tathlith and of Wadi Bisha which indicates the low rainfall with high infiltration rate.

\section{Stream Frequency}

Stream frequency (Fs) of the catchment is influenced by relief, infiltration capacity, and permeability of the watershed. It is calculated from the total number of stream segments of all orders divided by area of watershed [63]. It depends on the drainage density, initial resistivity of rock, and rainfall. Stream frequency was found to be 0.04 and 0.045 for Wadi Tathlith and Bisha watersheds respectively, and all the subwatersheds (Table 5) from Tathlith and Bisha shows very low stream frequency and poor drainage network. The low value of Fs indicates less rock permeability, low relief, and a low slope in the watershed.

\section{Elongation Ratio}

Elongation ratio $(\mathrm{Re})$ is a significant index of the catchment shape. The value of elongation ratio varies from 0 to 1 , where 0 suggests maximum elongation and1 indicates maximum circulatory shape representing the hydrological characteristics of the watershed [71]. The elongation ratio was 0.38 and 0.33 for Wadi Tathlith and Wadi Bisha watersheds, respectively. The computed value indicates the elongated characteristics for both the watersheds.

\section{Circulatory Ratio}

Circulatory ratio $(\mathrm{Rc})$ is an important indicator and depends on the climate, geological structure, slope, stream frequency, drainage density, and relief of the watersheds. Its value varies between 0 to 1 , which defines the minimum to maximum circulatory shape [28]. The value of the circulatory ratio is found to be 0.38 for Tathlith and 0.33 for Bisha watershed which reveals the elongated shape and less peak flow because of geomorphological adjustment.

\section{Form Factor}

Form factor ( $\mathrm{Rf}$ ) is described as the ratio of the catchment area to the square of the basin length which shows the intensity of flow and shape of the watershed [26]. The perfect circular basin has a form factor of $<0.78$ and its value of 0 indicates an elongated shape. The higher form factor indicates, the circular shape of the catchment which is prone to high peak flow in the shorter duration but in the basin with elongated shape, flood flows are easier to control than circular shape basin $[60,75,76,79]$. The value of the form factor calculated for Wadi Tathlith is 0.1 and 0.085 for the Bisha watershed. The lower value of both the watershed indicates an elongated shape with less peak flow with longer duration with a low water regime. The studies suggest that the higher value of form factor generally has the high peak flow in a short duration whereas the watershed with an elongated shape and low form factor will have a relatively flat peak flow for a longer duration $[67,80,81]$. The form factor among all the subwatersheds is found to be very low in the study area.

\section{Infiltration Number}

Infiltration number (If) is calculated from drainage density and frequency of stream which gives information about the infiltration rate. The calculated infiltration number is very low (0.014) for both the watershed.

\section{Constant Channel Maintenance and Length of Overland Flow}

Constant channel maintenance (C) and length of overland flow (Lof) is a function of density as described by Horton [63] and it plays a significant role in hydrological and physiographical development of catchment areas [60] Constant channel maintenance represents the area that is necessary to maintain one unit of length of stream (channel length) and define the erodibility of watershed [67]. Schumn [82] suggested that the drainage density can be utilized as a reciprocal for estimating the constant channel maintenance.. The value of constant channel maintenance is found to be 3.00 and 3.14 for Tathlith and Bisha watershed, respectively. Similarly, the constant channel maintenance value for the sub-watersheds varies between 2.78 minimum (TSW3) and 3.33 maximum (BSW5) in the study area (Table 5). The lower value of constant channel maintenance represents the potential of flood and the young stage of geomorphological development. A lower value $(<3)$ of constant channel maintenance was found for BSW2, TSW2, TSW3, and TSW6 which reflect relatively low infiltration, permeability, and vegetation cover. On the other hand, higher values were found for in TSW1, TSW4, TSW5, BSW1, BSW3, BSW4, and BSW5 sub-watersheds which reflect the higher infiltration and permeability and fair amount of vegetation cover.

The length of overland flow (Lof) defines the distance where rainwater must travel before it accumulated into the stream channel. According to Horton [63], drainage density can be used as a reciprocal to estimate the length of overland flow. The length of overland flow shows water movement over the soil surface until it joins to main drainage channel. The value of Lof is found to be 1.50 for Tathlith and 
1.57 for the Bisha watershed, which signifies low relief and slope. The movement of water is less, and it enters the stream in a longer duration. The value of the length of the overland flow value varies from 5.46 (BSW2) to 6.67 (BSW5) in all the sub-watersheds which suggests that rainwater has to travel over $5.46 \mathrm{~km}$ before it gets accumulated in stream channel in BSW2 sub-watersheds. A lower value will result in large surface runoff in the stream [83]. The watersheds with a high value of the length of overland flow may be characterized by the maturity of geomorphological features [84]. Table 3 represents the morphometric areal aspect parameters for the watersheds in the study area.

\section{Relief Parameters}

\section{Basin Relief}

Basin relief ( $\mathrm{Bh})$ is related to geomorphic processes and characteristics of the landform of the watershed. The absolute and relative relief is derived from the maximum difference in altitude. Basin relief is mainly influenced by the drainage characteristics, geomorphology, and underlying geology of the area. The altitude values range from $717 \mathrm{~m}$ to $2979 \mathrm{~m}$ for
Tathlith watershed and for Bisha watershed it ranges from $830 \mathrm{~m}$ to $2991 \mathrm{~m}$. The basin relief is found to be $2.26 \mathrm{~km}$ and $2.16 \mathrm{~km}$ for Tathlith and Bisha watersheds, indicating higher erosional and denudational rates in the basin.

\section{Relief Ratio}

Relief ratio ( $\mathrm{Rh}$ ) is the function of total basin relief and the length of the main stream [71]. It depends on different aerial and relief characteristics such as high basin relief, basin shape, and basin area of the catchment. The relief ratio for Tathlith and Bisha watersheds are found to be 0.0047 and 0.0039 respectively. It is evident the lower degree of slope is prominent in most parts of the watershed.

\section{Ruggedness Number}

Ruggedness number ( $\mathrm{Rn})$ is calculated from the basin relief and drainage density of the catchment and mainly depends on geomorphology, underlying geology, slope steepness, vegetation cover, and climate of the region.. The ruggedness number for Wadi Tathlith and Bisha watershed are found to be 0.75 and 0.68 ,

Table 3. Aerial and relief aspect morphometric parameters for watersheds.

\begin{tabular}{|c|c|c|}
\hline Morphometric parameters & Wadi Tathlith & Wadi Bisha \\
\hline Area $\left(\mathrm{km}^{2}\right)$ & 26298.7 & 26680 \\
\hline Perimeter $(\mathrm{km})$ & 1501.92 & 1824.3 \\
\hline Basin Length $(\mathrm{km})$ & 480.58 & 557.07 \\
\hline Stream Order & 6 & 6 \\
\hline Total Stream of all order (Nu) & 1071 & 1215 \\
\hline Total length of streams in all order (Lu) & 8759.36 & 8474.94 \\
\hline Mean Bifurcation Ratio (Rbm) & 4.02 & 4.04 \\
\hline Basin relief Bh $(\mathrm{km})$ & 2.262 & 2.161 \\
\hline Relief Ratio $(R h)$ & 0.0047 & 0.00388 \\
\hline Ruggedness Number (Rn) & 0.7534 & 0.68644 \\
\hline Drainage Density $(D d)(\mathrm{km} / \mathrm{km} 2)$ & 0.3331 & 0.31765 \\
\hline Stream Frequency $(F s)$ & 0.0407 & 0.04554 \\
\hline Infiltration Number (If) & 0.0136 & 0.0145 \\
\hline Texture (T) & 0.5586 & 0.5202 \\
\hline Form Factor (Rf) & 0.1139 & 0.08597 \\
\hline Circularity ratio $(R c)$ & 0.1464 & 0.10069 \\
\hline Elongation ratio $(\mathrm{Re})$ & 0.3809 & 0.33094 \\
\hline Length of Overland Flow (Lof) & 1.5 & 1.57 \\
\hline Constant Channel Maintenance (c) & 3 & 3.14 \\
\hline Compactness coefficient (Cc) & 2.6127 & 3.1507 \\
\hline
\end{tabular}


respectively. Wadi Tathlith have higher ruggedness number from Bisha watershed which reveals that the peak discharge is likely to be relatively high in Wadi Tathlith compared to Bisha watershed. The calculated morphometric parameters for Wadi Tathlith and Wadi Bisha watersheds are given in Table 3.

\section{Sub-Watershed Morphometric Analysis}

Morphometric parameters have been calculated at the sub-watershed level for Wadi Tathlith and Wadi Bisha sub-watershed. Total 6 sub-watersheds (TSW1, TSW2, TSW3, TSW4, TSW5, TSW6) for Wadi Tathlith and 5 sub-watersheds (BSW1, BSW2, BSW3, BSW4, BSW5) for Wadi Bisha have been identified for the detailed assessment of morphometric analysis on the sub-watershed level. The calculated linear aspect, areal, and relief morphometric parameters for sub-watersheds of Wadi Tathlith and Wadi Bisha are given in Table 4 and Table 5 respectively.

The morphometric analysis shows that from the linear aspect, higher stream network can be observed in TSW4, and TSW5 for Wadi Tathlith whereas BSW3 and BSW4 have a higher number of drainages in Wadi Bisha. The remaining sub-watersheds show poor drainage network. There is not much variation observed in stream number and stream order. The stream length varies from 953 to $2831 \mathrm{~km}$ across all the stream orders in Tathlith, whereas, in Bisha comparatively 587 to $2761 \mathrm{~km}$ of variation can be observed in the subwatershed (Table 4). It is observed (Table 5) that the mean stream length value is higher in TSW1, TSW3, TSW6 whereas only BSW2 has a higher value of mean stream length which indicates that these sub-watersheds have a relatively higher runoff. Texture value indicates that both the watershed has coarse texture, favorable for high infiltration, and the stream frequency is found to be very low indicating poor drainage network in the watersheds. The elongation ratio of sub-watershed of Wadi Tathlith shows consistency and TSW4, TSW5 and TSW6 show a comparatively high value compared to other sub-watersheds which represent that TSW4, TSW5, and TSW6 has comparatively high relief and slope.

The statistical analysis was conducted for the morphometric parameter of the sub-watersheds in the study region. The statistical significance of interrelationship of parameter assists to empathize the terrain characteristics for the management and planning of the basin. Pearson's correlation matrix was calculated, and values were quantitatively analyzed for the Wadi Tathlith (Table 6) and Wadi Bisha watershed (Table 7).

\section{Sub-watershed Prioritization}

Wadi Tathlith and Wadi Bisha sub-watersheds of Asir province have been quantitatively analyzed based on the detailed morphometric assessment to

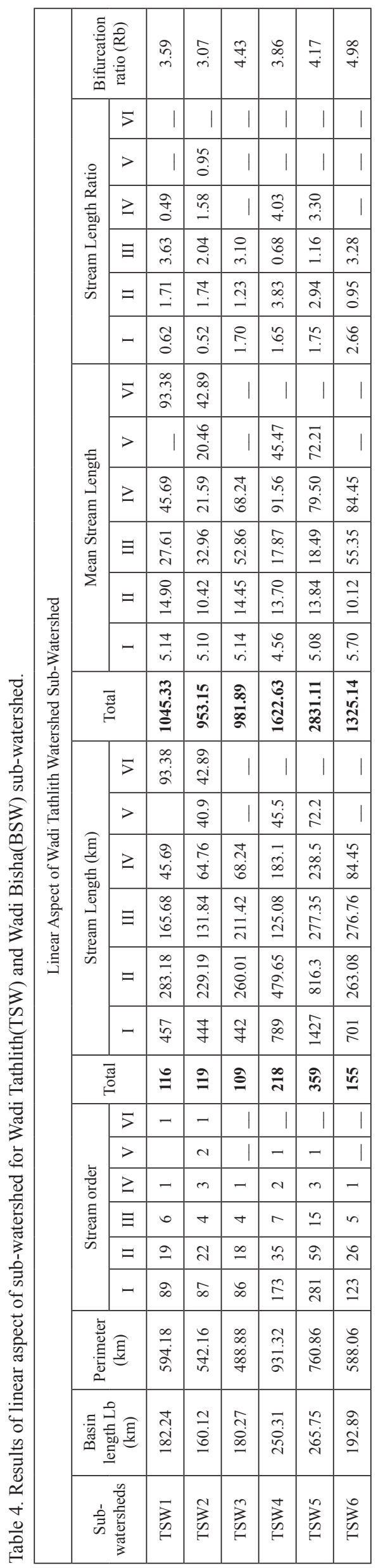




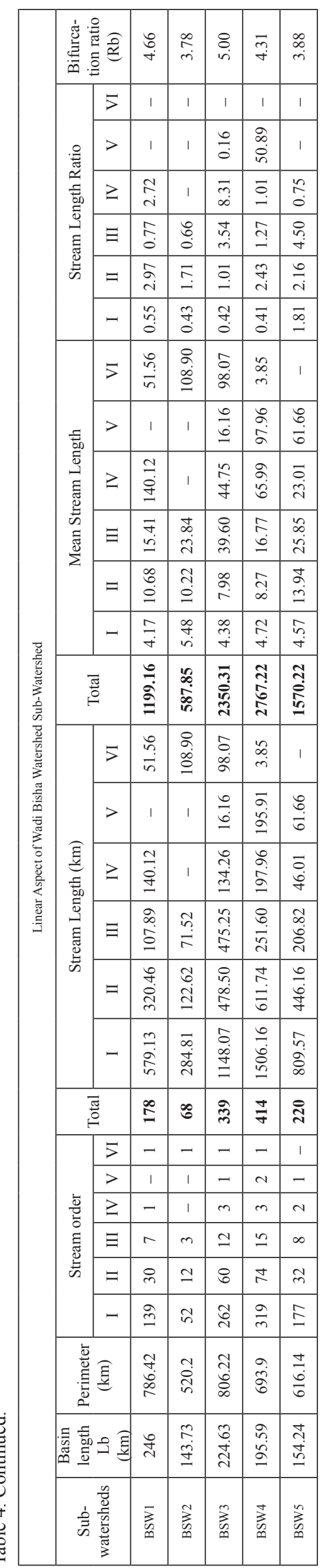

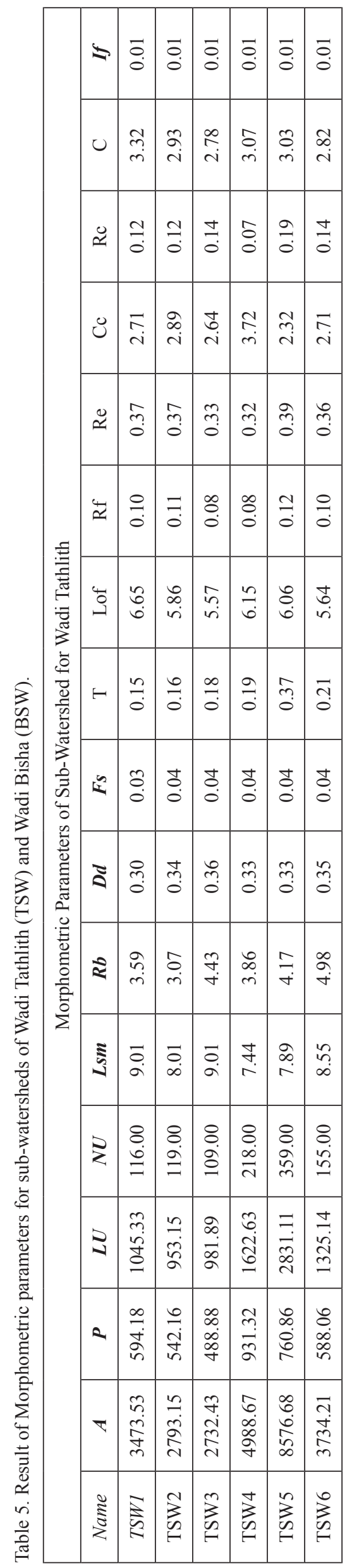




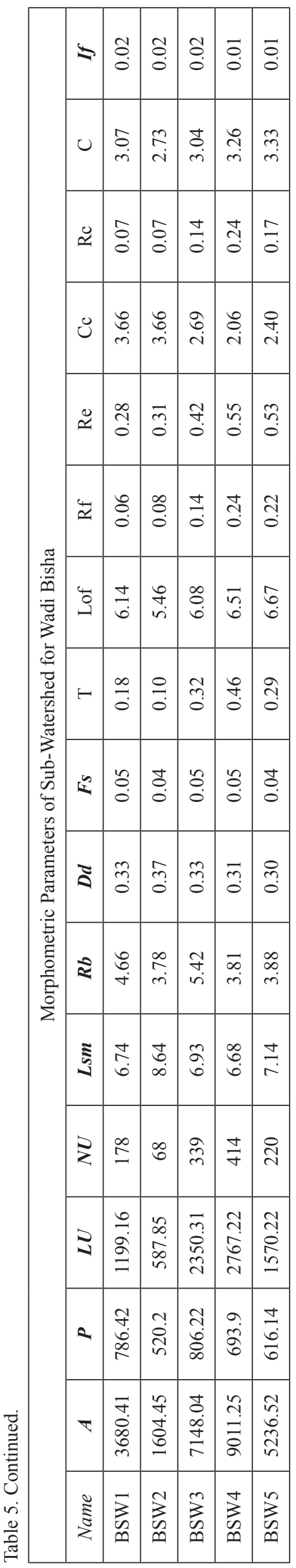

understand the watershed characteristics, hydrological and denudational mechanism. Based on the watershed characteristics, prioritization of sub-watershed has been carried out for watershed restoration, management, conservation, and developmental planning. The parameters from the linear aspect such as bifurcation ratio, drainage density, texture, stream frequency, and length of overland flow, have direct control on the erodibility of the watershed The higher value of these parameters reflects high erodibility in the region. On the other hand, these parameters have inverse relationship s with elongation ratio, circulatory ratio, and form factor [65]. Table 8 and 9 shows the morphometric parameters with compound values and priority vector in Wadi Tathlith and Wadi Bisha watershed for restoration planning.

The compound value $(\mathrm{Cp})$ was derived for eleven sub-watersheds from Bisha and Tathlith using the linear and shape parameters. The lower compound value indicates high rank and is labeled as high priority. On the other hand, high compound value indicates relatively low rank and has been labeled as medium and low priority, respectively. In this study, eleven subwatersheds were grouped into three categories such as "High", "Medium", and "Low" on the basis of rank and priorities. The result from the study reveals that the TSW1, TSW2, TSW3, TSW5 and BSW2, BSW4 subwatersheds reflect low compound values, and ranges from a minimum of 1.441 (TSW2) to a maximum of 1.58 (BSW4). These watersheds have been categorized as 'high priority' amongst all the sub-watersheds. The sub-watersheds where compound value ranges from a minimum of 1.6 (BSW5) to a maximum of 1.64 (TSW4) are categorized as 'medium priority'. The watersheds BSW1 and BSW3 were categorized as "low priority" because these sub-watersheds have relatively high compound values. The prioritized sub-watersheds for Wadi Tathlith and Wadi Bisha are shown Figs 3 and 4.

\section{Validation}

The prioritization of sub-watersheds based on the compound value was validated through the water yield from borewells in the region. The water yield data from Ministry of Environment, Water and Agriculture, Saudi Arabia for the year 2016-2017 for borewells that are present in different watersheds of Wadi Bisha and Tathlith were collected. The water yield data was not available for TSW1 and BSW1 sub-watershed, however rest of the watersheds were found to have at least one monitoring well. The water yield in highly prioritized sub-watersheds TSW2, TSW3, TSW5, BSW2, and BSW4 were observed to be around 110, 170, 77, 90, and $70 \mathrm{~m}^{3} /$ day respectively. All high prioritized subwatersheds but TSW3 in Tathlith showed low water yield compared to that categorized as medium or low. The anomalous and relatively good water yield (170 m²/day) in TSW3 was found to be exception, which could be because of influence of some local hydrogeological 


\begin{tabular}{|c|c|c|c|c|c|c|c|c|c|c|c|c|c|c|c|c|c|}
\hline & $\approx$ & & & & & & & & & & & & & & & & 8 \\
\hline & u & & & & & & & & & & & & & & & $\stackrel{8}{.}$ & $\stackrel{0}{\circ}$ \\
\hline & $\cong$ & & & & & & & & & & & & & & $\underset{-}{8}$ & 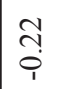 & 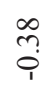 \\
\hline & ن & & & & & & & & & & & & & $\underset{-}{\stackrel{-}{\circ}}$ & $\stackrel{n}{2}$ & $\frac{n}{0}$ & $\begin{array}{l}\dot{0} \\
\dot{0}\end{array}$ \\
\hline & $\approx$ & & & & & & & & & & & & 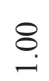 & $\vec{r}$ & $\stackrel{R}{0}$ & $\underset{\tilde{O}}{0}$ & $\frac{ \pm}{0}$ \\
\hline 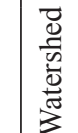 & $\$$ & & & & & & & & & & & $\stackrel{8}{-}$ & $\stackrel{8}{.}$ & $\begin{array}{l}R \\
i \\
i\end{array}$ & $\stackrel{R}{0}$ & สิ & $\frac{n}{0}$ \\
\hline 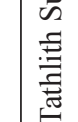 & $\Xi$ & & & & & & & & & & $\stackrel{8}{-}$ & సิ & ָิ & $\stackrel{0}{0}$ & $\begin{array}{l}\tilde{T} \\
\text { ஸे }\end{array}$ & $\underset{-}{\stackrel{8}{0}}$ & $\stackrel{8}{\circ}$ \\
\hline $\begin{array}{l}: \vec{z} \\
3 \\
3 \\
z \\
0\end{array}$ & - & & & & & & & & & $\stackrel{8}{.}$ & o. & 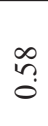 & $\begin{array}{l}0 \\
n \\
o n\end{array}$ & $\begin{array}{l}\infty \\
\stackrel{0}{0} \\
i\end{array}$ & $\vec{i}$ & $\begin{array}{l}\hat{0} \\
\dot{\varphi}\end{array}$ & $\frac{2}{0}$ \\
\hline 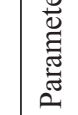 & $\Sigma$ & & & & & & & & $\stackrel{8}{-}$ & กี & $\begin{array}{l}\vec{b} \\
\dot{\varphi}\end{array}$ & $\frac{J}{i}$ & $\frac{n}{i}$ & $\tilde{m}$ & $\frac{m}{\dot{0}}$ & $\begin{array}{l}\vec{b} \\
\stackrel{0}{0}\end{array}$ & fo \\
\hline $\begin{array}{l}\overrightarrow{\tilde{E}} \\
\overline{0} \\
\overrightarrow{2}\end{array}$ & $\Xi$ & & & & & & & $\underset{-}{\stackrel{-}{*}}$ & $\begin{array}{l}n \\
\stackrel{n}{0}\end{array}$ & $\stackrel{t}{0}$ & $\underset{i}{8}$ & ṛ̂ & ָָ & $\stackrel{1}{0}$ & त̦ & $\underset{i}{\stackrel{8}{i}}$ & $\begin{array}{l}\text { ô } \\
\stackrel{0}{0}\end{array}$ \\
\hline 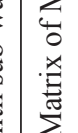 & $\gtrless$ & & & & & & $\stackrel{8}{.}$ & 苞 & $\stackrel{7}{0}$ & กี & กิ & $\frac{0}{0}$ & $\frac{\partial}{\dot{1}}$ & $\begin{array}{l}\hat{N} \\
\stackrel{i}{1}\end{array}$ & $\stackrel{+}{m}$ & $\begin{array}{l}\tilde{n} \\
\tilde{n} \\
i\end{array}$ & $\begin{array}{l}\text { to. } \\
\text { i }\end{array}$ \\
\hline 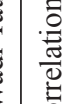 & క & & & & & $\stackrel{8}{.}$ & 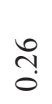 & oे & $\stackrel{\hat{n}}{i}$ & $\hat{n}$ & $\begin{array}{l}\text { to } \\
\text { in }\end{array}$ & $\begin{array}{l}\text { to } \\
\text { i. }\end{array}$ & $\begin{array}{l}\text { ô. } \\
\text { ì }\end{array}$ & $\begin{array}{l}4 \\
n \\
i \\
?\end{array}$ & i़ & $\begin{array}{l}\text { to } \\
0\end{array}$ & $\begin{array}{l}\stackrel{R}{0} \\
0\end{array}$ \\
\hline & $z$ & & & & $\stackrel{8}{.}$ & $\begin{array}{l}\overline{0} \\
\stackrel{0}{0}\end{array}$ & $\stackrel{5}{0}$ & $\frac{0}{0}$ & 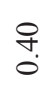 & $\hat{o}$ & $\stackrel{\simeq}{\circ}$ & $\frac{7}{0}$ & $\underset{\sigma}{\vec{\sigma}}$ & $\frac{1}{0}$ & $\stackrel{?}{f}$ & $\stackrel{\sim}{\circ}$ & $\begin{array}{l}n \\
\infty \\
i \\
i\end{array}$ \\
\hline & $\stackrel{2}{3}$ & & & $\underset{-}{8}$ & gे & $\begin{array}{l}n \\
\hat{n} \\
i\end{array}$ & สิ & $\frac{n}{0}$ & $\stackrel{m}{?}$ & $\stackrel{\circ}{\circ}$ & $\stackrel{7}{0}$ & $\stackrel{\infty}{+}$ & $\stackrel{0}{0}$ & 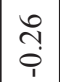 & $\vec{n}$ & $\stackrel{\sim}{\div}$ & $\begin{array}{l}0 \\
\infty \\
\infty \\
1\end{array}$ \\
\hline & 2 & & $\stackrel{8}{8}$ & $\overrightarrow{0}$ & ڤ్ర & $\begin{array}{c}\infty \\
\substack{0 \\
i}\end{array}$ & $\begin{array}{l}\qquad \\
\stackrel{0}{0} \\
\dot{c}\end{array}$ & $\begin{array}{l}F \\
\dot{p}\end{array}$ & F. & $\hat{3}$ & $\hat{\tilde{o}}$ & $\begin{array}{l}0 \\
\stackrel{1}{1}\end{array}$ & $\frac{\infty}{\varphi_{1}^{\prime}}$ & ڤ్ & 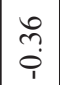 & n़? & $\begin{array}{l}n \\
n \\
i\end{array}$ \\
\hline & $\nabla$ & $\underset{-}{8}$ & ¿ & $\stackrel{8}{8}$ & gे & 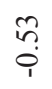 & $\stackrel{0}{0}$ & $\begin{array}{l}\text { ñ } \\
\text { ch }\end{array}$ & $\hat{\widehat{o}}$ & to & $\vec{\jmath}$ & $\stackrel{q}{q}$ & f. & 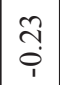 & $\stackrel{\infty}{\stackrel{\infty}{0}}$ & $\vec{\jmath}$ & 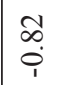 \\
\hline & & $\varangle$ & $a$ & 马ص? & Z & 结 & 의 & $\bar{\Omega}$ & is & $\mapsto$ & 岁 & $\underline{\underline{T}}$ & $\mathscr{\simeq}$ & ن & $\ddot{\sim}$ & U & $\Psi$ \\
\hline
\end{tabular}




\begin{tabular}{|c|c|c|c|c|c|c|c|c|c|c|c|c|c|c|c|c|}
\hline & & & & & & & & & & & & & & & & 8 \\
\hline & & & & & & & & & & & & & & & $\stackrel{8}{\circ}$ & 尺े \\
\hline & & & & & & & & & & & & & & 8 & $\stackrel{0}{2}$ & $\begin{array}{l}\infty \\
0 \\
0\end{array}$ \\
\hline & & & & & & & & & & & & & $\stackrel{8}{.}$ & $\hat{a}$ & $\stackrel{2}{0}$ & 尺 \\
\hline & & & & & & & & & & & & $\stackrel{8}{-}$ & $\stackrel{\infty}{2}$ & $\stackrel{2}{\circ}$ & $\stackrel{\infty}{\stackrel{\infty}{\sim}}$ & $\bar{\infty}$ \\
\hline & & & & & & & & & & & $\stackrel{8}{-}$ & $\stackrel{8}{8}$ & â. & 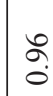 & $\mid \begin{array}{l}\infty \\
\infty \\
0\end{array}$ & $\mid \begin{array}{c}\infty \\
\infty \\
0 \\
1\end{array}$ \\
\hline & & & & & & & & & & $\stackrel{8}{-}$ & $\begin{array}{l}\infty \\
\infty \\
0\end{array}$ & $\stackrel{\infty}{\stackrel{\infty}{0}}$ & $\stackrel{2}{0}$ & i & $\stackrel{8}{\circ}$ & 응 \\
\hline & & & & & & & & & $\stackrel{\leftrightarrow}{\circ}$ & $\underset{\stackrel{t}{0}}{\stackrel{+}{0}}$ & {$\left[\begin{array}{l}\mathscr{2} \\
\infty \\
0\end{array}\right.$} & $\stackrel{\infty}{\infty}$ & ڤ̊. & Jे & $\stackrel{+}{0}$ & fr \\
\hline & & & & & & & & $\stackrel{8}{-}$ & $\stackrel{\sim}{\sim}$ & $\begin{array}{l}\hat{0} \\
0\end{array}$ & 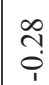 & 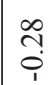 & $\stackrel{8}{0}$ & 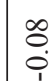 & $\stackrel{0}{0}$ & ถุ? \\
\hline & & & & & & & $\stackrel{8}{.}$ & $\frac{m}{0}$ & $\begin{array}{l}n \\
\stackrel{0}{0}\end{array}$ & $\underset{-1}{8}$ & î & $\stackrel{n}{\stackrel{0}{i}}$ & $\stackrel{\infty}{\stackrel{\infty}{0}}$ & $\stackrel{n}{\stackrel{2}{i}}$ & $\underset{1}{8}$ & $\stackrel{2}{0}$ \\
\hline & & & & & & $\underset{-}{8}$ & $\stackrel{\tilde{O}}{\circ}$ & $\stackrel{\overbrace{}}{0}$ & O. & $\begin{array}{l}\infty \\
\stackrel{0}{0} \\
\stackrel{1}{1}\end{array}$ & $\stackrel{\text { ?े }}{i}$ & 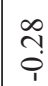 & $\stackrel{7}{\circ}$ & 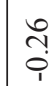 & $\begin{array}{l}\infty \\
0 \\
0 \\
\end{array}$ & 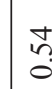 \\
\hline & & & & 8 & & $\begin{array}{l}q \\
\dot{q} \\
i \\
i\end{array}$ & $\underset{\mathscr{\infty}}{\mathscr{\infty}}$ & $\begin{array}{l}5 \\
0 \\
i\end{array}$ & $\begin{array}{l}R \\
i \\
i\end{array}$ & $\stackrel{\hat{\rho}}{\hat{i}}$ & 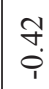 & 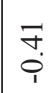 & $\tilde{n}$ & $\begin{array}{l}\text { బ̂. } \\
\text { ? }\end{array}$ & 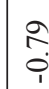 & 尺્ર \\
\hline & & & 8 & 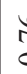 & & ָุ & $\widehat{\delta}$ & ?f & à. & $\hat{0}$ & $\stackrel{ }{0}$ & 尺ิ & $\stackrel{\substack{+0}}{0}$ & $\begin{array}{l}+ \\
\infty \\
0\end{array}$ & $\tilde{2}$ & â \\
\hline & & $\stackrel{8}{.}$ & $£$ & i & & 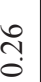 & $\begin{array}{l}0 \\
: \\
:\end{array}$ & F & $\hat{a}$ & ț & $\stackrel{\mathbb{2}}{\stackrel{0}{0}}$ & $\stackrel{\Re}{\circ}$ & $\stackrel{0}{\infty}$ & 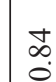 & t: & ֶֻ \\
\hline & $\stackrel{8}{-}$ & n? & in & $\oint$ & & 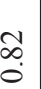 & $\begin{array}{l}\infty \\
\substack{n \\
i}\end{array}$ & $\hat{\sigma}$ & ले & तै? & $\stackrel{8}{\circ}$ & $\stackrel{2}{2}$ & $\frac{ \pm}{0}$ & $\stackrel{\infty}{\circ}$ & ?ै? & 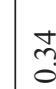 \\
\hline & तु & $\stackrel{8}{.}$ & 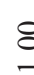 & 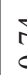 & & તุ. & $\vec{i}$ & $\hat{m}$ & g. & : & î & $\stackrel{\infty}{\stackrel{\infty}{0}}$ & $\begin{array}{l}\infty \\
0 \\
0\end{array}$ & $\begin{array}{l}\infty \\
\infty \\
0\end{array}$ & $: 0$ & $\stackrel{m}{0}$ \\
\hline & $a$ & 马 & $\bar{z}$ & 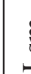 & & حै & $\vec{\Delta}$ & $\infty$ & $H$ & 亗 & $\widetilde{L}$ & $\widetilde{\simeq}$ & ن & $\mathscr{\sim}$ & U & $\Psi$ \\
\hline
\end{tabular}




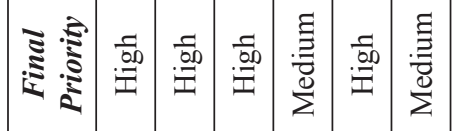

咅

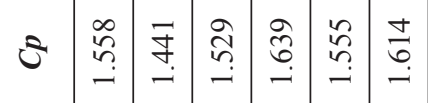

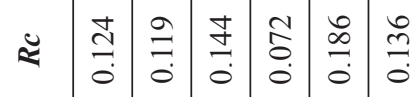

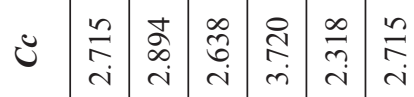

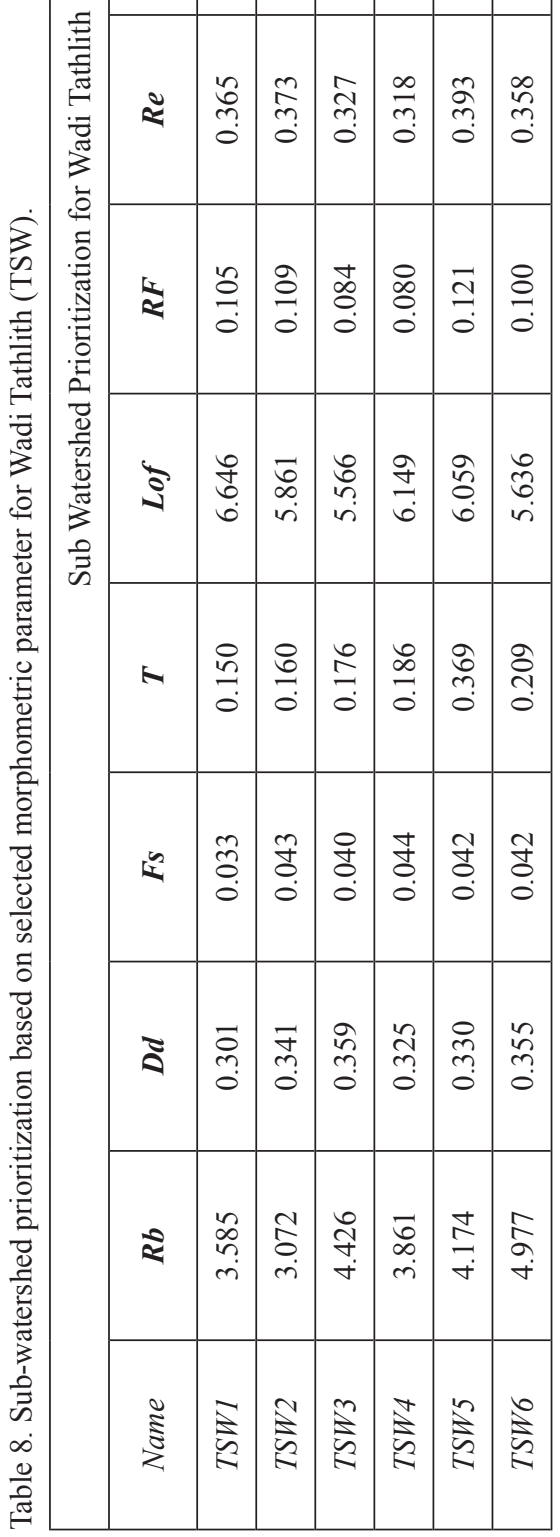

\begin{tabular}{|c|c|c|c|c|c|c|}
\hline & (3) & $\mid \begin{array}{l}3 \\
0 \\
- \\
9\end{array}$ & $\begin{array}{l}\overline{50} \\
\stackrel{50}{ \pm}\end{array}$ & 登 & 竞 & 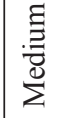 \\
\hline & $\stackrel{\Xi}{\Xi}$ & $\circ$ & $m$ & $=$ & 0 & r \\
\hline & s & $\vec{I}$ & 芯 & $\stackrel{?}{=}$ & $\stackrel{\infty}{\stackrel{\infty}{\longrightarrow}}$ & $\underset{-\sigma}{\sigma}$ \\
\hline & $\ddot{z}$ & $\stackrel{5}{0}$ & $\begin{array}{l}0 \\
0 \\
0\end{array}$ & $\stackrel{ \pm}{0}$ & ป̊ & $\frac{1}{0}$ \\
\hline & ن & $\begin{array}{l}\mathscr{0} \\
\dot{r}\end{array}$ & $\begin{array}{l}8 \\
\dot{0} \\
\dot{n}\end{array}$ & $\begin{array}{l}\hat{\theta} \\
i\end{array}$ & $\begin{array}{l}\stackrel{0}{0} \\
\text { in }\end{array}$ & 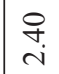 \\
\hline 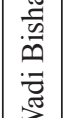 & $\approx$ & \begin{tabular}{l}
$\infty$ \\
\multirow{0}{0}{}
\end{tabular} & $\bar{n}$ & f. & $\begin{array}{l}n \\
n \\
0\end{array}$ & $\hat{n}$ \\
\hline 胥 & 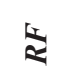 & $\stackrel{0}{\circ}$ & 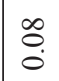 & $\frac{ \pm}{0}$ & 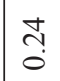 & ֶָ. \\
\hline 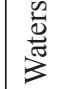 & s & $\underset{6}{ \pm}$ & $\begin{array}{l}0 \\
\text { in. } \\
\text { in }\end{array}$ & $\begin{array}{l}\infty \\
0 \\
0\end{array}$ & $\vec{n}$ & $\begin{array}{l}\hat{6} \\
0\end{array}$ \\
\hline & $H$ & $\stackrel{\infty}{0}$ & $\stackrel{0}{0}$ & శై & 号 & సેे \\
\hline & 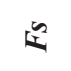 & $\stackrel{1}{0}$ & ¿ & $\stackrel{n}{0}$ & $\begin{array}{l}2 \\
0 \\
0\end{array}$ & 苛 \\
\hline & $\Xi$ & $\stackrel{m}{3}$ & $\tilde{n}$ & $\begin{array}{l}n \\
\tilde{n}\end{array}$ & $\bar{n}$ & 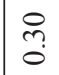 \\
\hline & $\vec{z}$ & $\begin{array}{l}\stackrel{8}{\circ} \\
+\end{array}$ & $\stackrel{\infty}{\stackrel{\infty}{\sim}}$ & 勇 & \begin{tabular}{|l}
$\vec{\infty}$ \\
$\dot{r}$
\end{tabular} & $\begin{array}{c}\infty \\
\infty \\
\infty\end{array}$ \\
\hline & $\frac{\tilde{z}}{z}$ & $\begin{array}{c}\bar{\omega} \\
\overline{0}\end{array}$ & 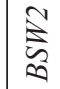 & $\frac{n}{5}$ & 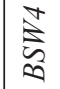 & $\frac{n}{n}$ \\
\hline
\end{tabular}




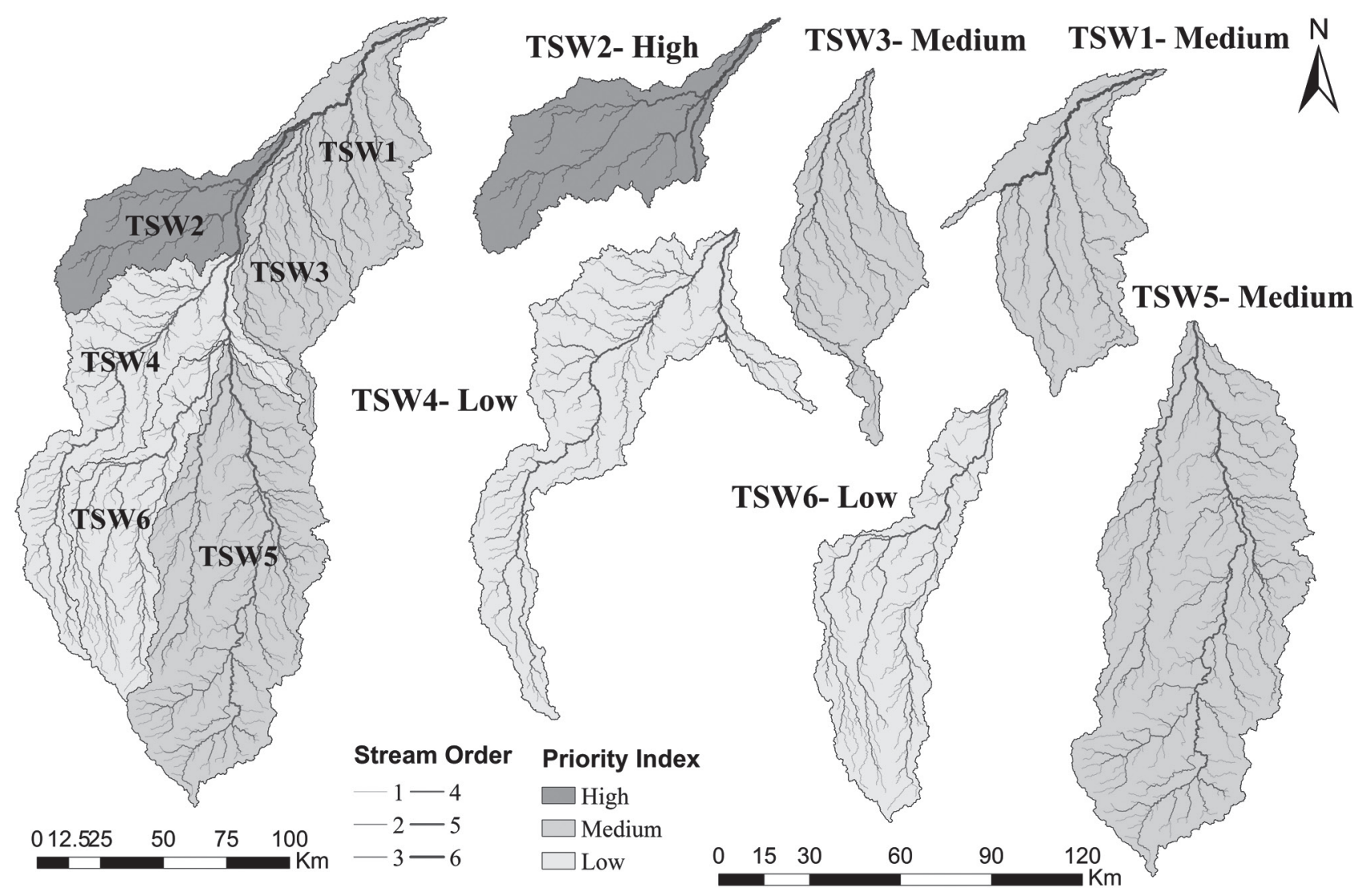

Fig. 3. Watershed prioritization in Tathlith Watershed based on compound score values (Cp).

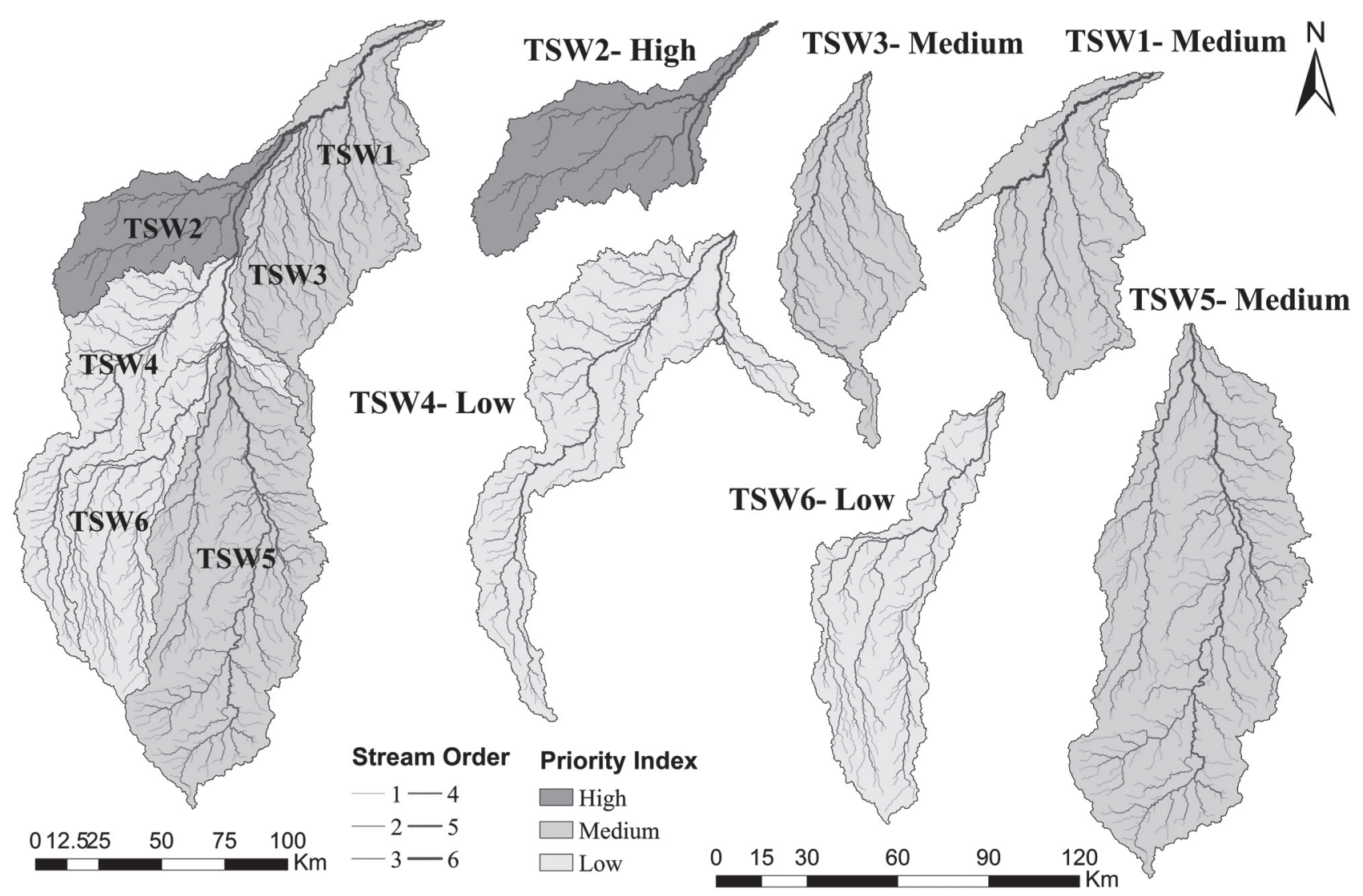

Fig. 4. Watershed prioritization in Bisha Watershed based on compound score values (Cp). 


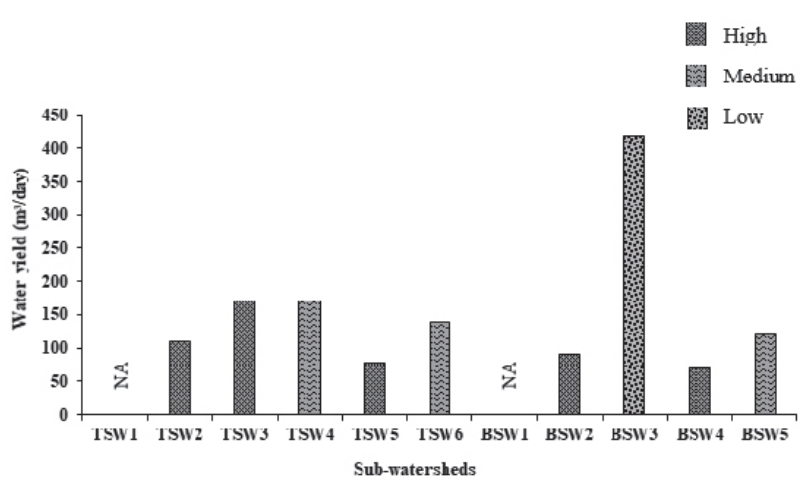

Fig. 5. Water yield and prioritization of sub-watershed in Bisha and Tathlith.

factors. The water yield in sub-watersheds categorized as medium prioritized such as TSW4, TSW6, and BSW5 was observed to be around 170, 140, and $120 \mathrm{~m}^{3} /$ day whereas high water yield was measured in low priority sub-watersheds and found to be $420 \mathrm{~m}^{3} /$ day for BSW3 in the Bisha watershed (Fig. 5). The water yields from the borewells validated the findings of the study.

\section{Discussion}

The morphometric characteristics exhibiting the configurations of the Bisha and Tathlith watersheds which helps to understand the structural control, hydrological mechanism, and denudational process of the hydrological unit to prioritize the watersheds for soil and water conservation measures in Asir region. There are several morphometric parameters that were analyzed for both the watersheds, Tathlith and Bisha, in the study. The stream order, stream number, stream length, mean stream length, stream length ratio and bifurcation ratio were analyzed under linear aspect of the watersheds. It is observed that with the increase of stream order, the stream frequency decreases in Bisha and Tathlith watersheds, both of which exhibits the dendritic drainage pattern. It is observed that percentage of the first order stream in all the sub-watersheds ranges between $70-80 \%$, out of which minimum was found to be in TSW2 (73\%) and maximum in BSW5 $(80 \%)$. Furthermore, it has been observed in several studies that the number of stream segments decrease with increasing order of streams [34, 81, 82]. A large number of first-order streams represents that there is a possibility of a sudden or unexpected chance of flash floods after rainfall events [69, 83]. This is a good indicator of infiltration capacity and impermeability of the watershed which has a significant impact on the drainage system $[62,72,84]$. It also indicates that the rock beneath the drainage has no particular structure and can lead to erosion. The higher percentage of low order drainage segment (especially $1^{\text {st }}$ order) is found in both the watersheds which is due to mountainous and undulating young topography alongside streams. The change in stream order, $2^{\text {nd }}$ and $3^{\text {rd }}$ order, represents the major morphological alteration in both the watersheds. The low number of higher-order drainage in both the watershed indicates the development of alluvial plain (Fig. 2a). A high stream frequency reflects low permeability and low infiltration capacity, and as a result, a large part of water would result in the high runoff. The studies related to drainage morphometry have revealed that the length of total streams and the area of watersheds are important for understanding the average annual runoff in the watershed [64]. According to Morisawa 1962, the total stream length from each watershed is directly related to the mean annual runoff $[64,66]$. The mean stream length shows that the annual runoff is higher throughout all the stream order and significant higher runoff is observed in $4^{\text {th }}$ and $6^{\text {th }}$ order stream which indicate moderate to high flood regime. Bisha watershed exhibits less mean annual runoff and low water regime compared to Tathlith watershed. Higher stream order is related to greater discharge [85]. The significant runoff can be seen from the $5^{\text {th }}$ order stream and onwards, indicating morphological adjustments and geomorphic development in the region. This is complemented by the fact that the watersheds in the region develop flash floods during the months of April and May in the Asir region. Many studies carried out on different basin/watersheds of the world $[62,72,84,86]$ suggest that the basin without having differential geological control, their mean bifurcation ratio ranges vary between three and five. The high value of mean bifurcation value indicates the availability of rocks with high slopes and low permeability, whereas, the low values suggests that the rocks in the basin are characterized by low structural control with high permeability $[73,74,84]$. In the present study the mean bifurcation ratio was found to be $\sim 4$ which depicts that enough water is received in the upper reaches resulting into moderate to high runoff. The drainage density, texture ratio, stream frequency, elongation ratio, circulatory ratio, form factor, infiltration number constant channel maintenance and length of overland flow were analyzed under the aerial aspect of morphometric parameters. According to Patton (1988) [87], erosion and dissection by overland flow occurs due to high drainage density areas, the runoff is mainly dominated by infiltration and subsurface flow [66]. The study reveals low drainage density and coarse structure with the elongated shape for both watersheds and signifies the low relief, low slope, high infiltration capacity and less peak flow in the watersheds. The form factor estimates that the less peak flow for longer duration. The length of overland flow shows that the movement of water is less in the watersheds and enter the mainstream in longer time interval. The drainage morphometry and constant channel maintenance indicates that areas with good forest cover, or high permeable surface or resistant rock type demonstrate the high value of constant channel maintenance and a low drainage density. Likewise, the contracting surface conditions reveal the low constant channel maintenance 
and high drainage density. The constant channel maintenance value varies between 2.78 to 3.33 which reflect the infiltration, permeability, and coverage of vegetation in the watersheds. Furthermore, the relief parameters indicate the erosional and denudational rate in the watersheds and low degree of slope in most part of the watersheds. It is observed from the study that the ruggedness number is higher in Tathlith watershed compared to watershed of Bisha which exhibits the peak flow is relatively high in Tathlith. It was observed that the relative peak discharge is directly related to ruggedness number indicating that the increase in relative peak discharge increases with increasing value of ruggedness number [87]. The low value of ruggedness indicates the watershed is mature and is in the denudational stage of erosion.

The correlation among the morphometric parameters were studied to understand the interdependencies of the variable. Total stream length (LU) shows a good correlation with area at a 0.01 significance level. Mean stream length (Lsm) is negatively correlated with stream frequency (Fs), and drainage density (Dd) is negatively correlated with overland flow length (Lof) and constant channel maintenance $(\mathrm{C})$. The overland flow length (Lof) has perfect consistency with the constant maintenance of the channel (C) at a significance level of 0.01 (Table 6). Table 7 represents the correlation among the morphometric parameters calculated from the Wadi Bisha watershed. In Wadi Bisha, form factor shows good correlation with elongation ratio and length of overland flow (Lof) has good correlation with constant channel maintenance (C) whereas drainage density (Dd) shows negative correlation with length of overland flow (LoF) and constant channel maintenance (C).

The sub-watershed prioritization based on the compound value shows the priority rank of watersheds of the catchment where soil and water conservation measures need to be implemented in the region. The sub-watersheds labeled as 'high priority' have relatively higher compound values with respect to linear morphometric parameters whereas they have lower compound value for the shape parameters. The higher, combined linear parameters, and lower combined, shape parameter value is indicative of relatively higher erodibility in these sub-watersheds and require considerable and immediate attention for the restoration and development. The result from this study signifies that the total area of sub-watersheds in Wadi Bisha, under high, medium, and low priority is $39.78 \%$, $19.62 \%$ and $40.58 \%$ respectively. In the Wadi Tathlith watershed, the area that require considerable attention is $66.83 \%$ under high priority and $33.16 \%$ under medium priority. However, the immediate intervention and well-designed action plan is required in four subwatersheds (TSW1, TSW2, TSW3, and TSW5) of Wadi Tathlith that constitutes $67 \%$ of the total area and two sub-watersheds (BSW2 and BSW4) in Wadi Bisha which occupies approximately $40 \%$ of total area. These prioritized sub-watersheds were validated through the water yield data from the borewell. The watersheds in high distress/priority in both the Wadi's shows low water yield potential. Similarly, as prioritization decreases, we find that the water yield potential decreases, thus substantiating that the adopted methodology can be replicated in regions under high water stress conditions. The sub-watersheds categorized under high priority should be directly considered for watershed restoration along with emphasis on soil and water conservation measures to improve the water potential in the region. The medium prioritized subwatersheds can be considered for sustainable watershed management and development once the conservation practices have been established within the highly prioritized watersheds.

There are several studies conducted in many parts of the world developing GIS based framework for watershed management and development using morphometric characteristics and prioritization based on the compound value. Arefin et al. 2020 made an assessment for prioritization of watershed for soil and water conservation at northern elevated tract in Bangladesh using morphometric parameters [82]. Abdeta et al., 2020 prepared a management plan and practices in Gidabo Basin, Ethiopia using morphometric characteristics where he suggested the conservation measure in prioritized watersheds [81]. Similarly various studies were identified [88-92] for sub watershed prioritization on a basin level. Present study develops a spatial framework for watershed prioritization using compound factor of morphometric parameters and suggests the prioritization of watershed where direct intervention needs to be implemented on a priority basis in water scarce area to rejuvenate and restore the water potential in the region.

\section{Conclusions}

The study examines the morphometric parameters of the Wadi Tathlith and Wadi Bisha watershed and its eleven sub-watersheds for a better understanding of its hydrological and denudational characteristics. The study presents the methodological approaches using remote sensing and GIS to estimate the watershed morphometric aspect rather than conventional methods to identify the critical watersheds in the Asir region. This study provides a basis for spatial framework for stakeholders to take rational strategies for soil and water conservation in watershed management where ground water and relevant data are not available. Prioritized critical watersheds require comprehensive watershed management planning and implementation with integrated approaches which may require other spatial aspects such as estimation of runoff and sediment yield and other surface cover and soil characteristics to plan the conservation measures in the area thus this study could be treated as future direction to develop intervention plan based on integrated approaches. 
Different watersheds face different problems and resource degradation such as hazards due to soil erosion, flash floods, runoff, and drought, etc. These problems can be tackled with a thorough study of the drainage network, lithology, soil characteristics, areal, shape, and relief factors of the respective watershed. GIS-based morphometric analysis can emphasize the presence or absence of structural control on drainage network, lithological/geological and geomorphological feature which in turn can be used to locate artificial recharge locations, groundwater potential and accordingly the structures like percolation tanks, check dams and recharge shafts can be built. The methodology employed in the study for watershed ranking focuses primarily on the need for watershed protection and restoration and therefore identifying the regions of major concerns for land degradation and rejuvenation of water resources. The sub-watershed prioritization can be used by the local government, policymakers, and planners to take up activities of soil conservation and build water harvesting structures to achieve sustainable development.

\section{Acknowledgments}

The authors extend their appreciation to the Deanship of Scientific Research at King Khalid University for funding this work through General Research Project under grant number (R.G.P2 /92/41) and (R.G.P1 /173/41).

\section{Conflict of Interest}

The authors declare no conflict of interest.

\section{References}

1. SUBYANI A.L.I.M. Hydrogeological and Hydrochemical Features of Wadi Adam, Makkah Al-Mukarramah Area. Earth Sci., 16, 2005.

2. AL-TURKI S. Water Resources in Saudi Arabia with Particular Reference to Tihama Asir Province 1995.

3. ISLAM S., ABDULLAH R.A.B., ALGAHTANI A., IRSHAD K., HIROL H. Performance of vapour pressure models in the computation of vapour pressure and evapotranspiration in Abha, Asir region, Saudi Arabia. Appl. Ecol. Environ. Res. 17, 9691, 2019.

4. TARAWNEH Q.Y., CHOWDHURY S. Trends of Climate Change in Saudi Arabia: Implications on Water Resources. Climate 6, 8, 2018.

5. MESHRAM S.G., SHARMA S.K. Prioritization of Watershed through Morphometric Parameters: A PCABased Approach. Appl. Water Sci. 7, 1505, 2017.

6. CHOWDHURY S., AL-ZAHRANI M. Characterizing Water Resources and Trends of Sector Wise Water Consumptions in Saudi Arabia. J. King Saud Univ. Sci. 27, 68, 2015.
7. AL SAUD M. Morphometric Analysis of Wadi Aurnah Drainage System, Western Arabian Peninsula. open Hydrol. J. 3, 2009.

8. HLAING K.T., HARUYAMA S., AYE M.M. Using GISBased Distributed Soil Loss Modeling and Morphometric Analysis to Prioritize Watershed for Soil Conservation in Bago River Basin of Lower Myanmar. Front. Earth Sci. China, 2, 465, 2008.

9. STOCKER T.F., QIN D., PLATTNER G.-K., TIGNOR M., ALLEN S.K., BOSCHUNG J., NAUELS A., XIA Y., BEX V., MIDGLEY P.M. Climate Change 2013: The Physical Science Basis. Contrib. Work. Gr. I to fifth Assess. Rep. Intergov. panel Clim. Chang. 1535, 2013.

10. KACEM L., IGMOULLAN B., MOKHTARI S., AMAR H., AGOUSSINE M. Morphometric Characterization of Upstream Mountainous Watershed Using Geographic Information System GIS: High Valley of Tifnoute High Moroccan Atlas. J Biodivers Env. Sci 5, 62, 2014.

11. BEZINSKA G., STOYANOV K. Modelling and HydroMorphometric Analysis of Sub-Watershed. A Case Study of Mesta River Southwestern Bulgaria. Eur. J. Geogr. 10, 77, 2019.

12. KARABULUT M.S., ÖZDEMIR H. Comparison of Basin Morphometry Analyses Derived from Different DEMs on Two Drainage Basins in Turkey. Environ. Earth Sci. 78, 1, 2019.

13. ALAM A., AHMED B., SAMMONDS P. Flash Flood Susceptibility Assessment Using the Parameters of Drainage Basin Morphometry in SE Bangladesh. Quat. Int. 575, 295, 2021.

14. HARBI H. Geology and Lithostratigraphy of the Ultramafic-Mafic Rocks and Associated Mineralizations, Wadi Khamal Area, West-Central Arabian Shield. J. King Abdulaziz Univ. Sci. 19, 119, 2008, doi:10.4197/ear.19-1.7.

15. AL KWATLI M.A., GILLOT P.Y., LEFÈVRE J.C., HILDENBRAND A. Morpho-Structural Analysis of Harrat Al Sham Volcanic Field Arabian Plate (Syria, Jordan, and Saudi Arabia): Methodology and Application. Arab. J. Geosci. 8, 6867, 2015.

16. EL BASTAWESY M. The Geomorphological and Hydrogeological Evidences for a Holocene Deluge in Arabia. Arab. J. Geosci. 8, 2577, 2015.

17. MAHONEY D.T., FOX J., AL-AAMERY N., CLARE E. Integrating Connectivity Theory within Watershed Modelling Part I: Model Formulation and Investigating the Timing of Sediment Connectivity. Sci. Total Environ. 740, 140385, 2020.

18. MAGESH N.S., CHANDRASEKAR N. GIS Model-Based Morphometric Evaluation of Tamiraparani Subbasin, Tirunelveli District, Tamil Nadu, India. Arab. J. Geosci. 7, 131, 2014.

19. FENTA A.A., YASUDA H., SHIMIZU K., HAREGEWEYN N., WOLDEAREGAY K. Quantitative Analysis and Implications of Drainage Morphometry of the Agula Watershed in the Semi-Arid Northern Ethiopia. Appl. Water Sci. 7, 3825, 2017.

20. BAJABAA S., MASOUD M., AL-AMRI N. Flash Flood Hazard Mapping Based on Quantitative Hydrology, Geomorphology and GIS Techniques (Case Study of Wadi Al Lith, Saudi Arabia). Arab. J. Geosci. 7, 2469, 2014.

21. RAI P.K., MOHAN K., MISHRA S., AHMAD A., MISHRA V.N. A GIS-Based Approach in Drainage Morphometric Analysis of Kanhar River Basin, India. Appl. Water Sci. 7, 217, 2017. 
22. OHMORI H. Changes in the Hypsometric Curve through Mountain Building Resulting from Concurrent Tectonics and Denudation. Geomorphology 8, 263, 1993.

23. WILlGOOSE C., HANCOCK G. Revisiting the Hypsometric Curve as an Indicator of Form and Process in Transport-Limited Catchment. Earth Surf. Process. Landforms, 23，611， 1998, doi:10.1002/(SICI)10969837(199807)23:7<611::AID-ESP872>3.0.CO;2-Y.

24. RAO K.N., LATHA P., KUMAR P.A., KRISHNA M. Morphometric Analysis of Gostani River Basin in Andhra Pradesh State, India Using Spatial Information Technology. Int. J. Geomatics Geosci. 1, 179, 2010.

25. BABU K.J., SREEKUMAR S., ASLAM A. Implication of Drainage Basin Parameters of a Tropical River Basin of South India. Appl. Water Sci. 6, 67, 2016.

26. HORTON R.E. Drainage-basin Characteristics. Eos, Trans. Am. Geophys. union, 13, 350, 1932.

27. HORTON R.E. Erosional Development of Streams and Their Drainage Basins; Hydrophysical Approach to Quantitative Morphology. Geol. Soc. Am. Bull. 56, 275, 1945.

28. MILLER V.C. Quantitative Geomorphic Study of Drainage Basin Characteristics in the Clinch Mountain Area, Virginia and Tennessee. Tech. Rep. (Columbia Univ. Dep. Geol. 3, 1953.

29. SMITH K.G. Standards for Grading Texture of Erosional Topography. Am. J. Sci. 248, 655, 1950.

30. STRAHLER A.N. Quantitative Geomorphology of Drainage Basins and Channel Networks.

31. ARNOUS M.O., ABOULELA H.A., GREEN D.R. Geo-Environmental Hazards Assessment of the North Western Gulf of Suez, Egypt. J. Coast. Conserv. 15, 37, 2011.

32. SYED N.H., REHMAN A.A., HUSSAIN D., ISHAQ S., KHAN A.A. Morphometric Analysis to Prioritize Sub-Watershed for Flood Risk Assessment in Central Karakoram National Park Using GIS/RS Approach. ISPRS Ann. Photogramm. Remote Sens. Spat. Inf. Sci. 4, 367, 2017.

33. FARHAN Y., ANABA O. A Remote Sensing and GIS Approach for Prioritization of Wadi Shueib MiniWatersheds (Central Jordan) Based on Morphometric and Soil Erosion Susceptibility Analysis. J. Geogr. Inf. Syst. 8, $1,2016$.

34. CHOUDHARI P.P., NIGAM G.K., SINGH S.K., THAKUR S. Morphometric Based Prioritization of Watershed for Groundwater Potential of Mula River Basin, Maharashtra, India. Geol. Ecol. Landscapes 2, 256, 2018.

35. YADAV S.K., SINGH S.K., GUPTA M., SRIVASTAVA P.K. Morphometric Analysis of Upper Tons Basin from Northern Foreland of Peninsular India Using CARTOSAT Satellite and GIS. Geocarto Int. 29, 895, 2014.

36. YADAV S.K., DUBEY A., SZILARD S., SINGH S.K. Prioritisation of Sub-Watersheds Based on Earth Observation Data of Agricultural Dominated Northern River Basin of India. Geocarto Int. 33, 339, 2018.

37. AHIRWAR R., MALIK M.S., SHUKLA J.P. Prioritization of Sub-Watersheds for Soil and Water Conservation in Parts of Narmada River through Morphometric Analysis Using Remote Sensing and GIS. J. Geol. Soc. India, 94, $515,2019$.

38. PATHARE J.A., PATHARE A.R. Prioritization of MicroWatershed Based on Morphometric Analysis and Runoff Studies in Upper Darna Basin, Maharashtra, India. Model. Earth Syst. Environ. 1, 2020.
39. KNIGHT J., GRAB S.W. Drainage Network Morphometry and Evolution in the Eastern Lesotho Highlands, Southern Africa. Quat. Int. 470, 4, 2018.

40. ABDULKAREEM J.H., PRADHAN B., SULAIMAN W.N.A., JAMIL N.R. Quantification of Runoff as Influenced by Morphometric Characteristics in a Rural Complex Catchment. Earth Syst. Environ. 2, 145, 2018.

41. SATHEESHKUMAR S., VENKATESWARAN S. Predilection of Sustainable Recharge Structures Using Morphometric Parameters and Decision Making Model in the Vaniyar Sub Basin, South India. Appl. Water Sci. 8, 1, 2018.

42. STEFANELLI C.T., VILÍMEK V., EMMER A., CATANI F. Morphological Analysis and Features of the Landslide Dams in the Cordillera Blanca, Peru. Landslides 15, 507, 2018.

43. ASFAW D., WORKINEH G. Quantitative Analysis of Morphometry on Ribb and Gumara Watersheds: Implications for Soil and Water Conservation. Int. Soil Water Conserv. Res. 7, 150, 2019.

44. YANG G., CHEN Z., JIANG J. Drainage Morphometry of the Lishui Catchment in the Middle Yangtze Basin, China: Morphologic and Tectonic Implications. Arab. J. Geosci. 13, 1, 2020.

45. JOTHIMANI M., ABEBE A., DAWIT Z. Mapping of Soil Erosion-Prone Sub-Watersheds through Drainage Morphometric Analysis and Weighted Sum Approach: A Case Study of the Kulfo River Basin, Rift Valley, Arba Minch, Southern Ethiopia. Model. Earth Syst. Environ. 6, 2377, 2020.

46. ARTEAGA J., OCHOA P., FRIES A., BOLL J. Identification of Priority Areas for Integrated Management of Semiarid Watersheds in the Ecuadorian Andes. JAWRA J. Am. Water Resour. Assoc. 56, 270, 2020.

47. RÓŻYCKA M., MIGOŃ P. Morphometric Properties of River Basins as Indicators of Relative Tectonic Activity - Problems of Data Handling and Interpretation. Geomorphology, 107807, 2021.

48. AHER P.D., ADINARAYANA J., GORANTIWAR S.D. Quantification of Morphometric Characterization and Prioritization for Management Planning in Semi-Arid Tropics of India: A Remote Sensing and GIS Approach. J. Hydrol. 511, 850, 2014.

49. JAISWAL R.K., THOMAS T., GALKATE R. V, GHOSH N.C., SINGH S. Watershed Prioritization Using Saaty's AHP Based Decision Support for Soil Conservation Measures. Water Resour. Manag. 28, 475, 2014.

50. DE STEIGUER J.E., DUBERSTEIN J., LOPES V. The Analytic Hierarchy Process as a Means for Integrated Watershed Management. In Proceedings of the First interagency conference on research on the watersheds; Agricultural Research Service, US Department of Agriculture, Agricultural ..., 736, 2003.

51. CHOWDARY V.M., CHAKRABORTHY D., JEYARAM A., MURTHY Y.V.N.K., SHARMA J.R., DADHWAL V.K. Multi-Criteria Decision Making Approach for Watershed Prioritization Using Analytic Hierarchy Process Technique and GIS. Water Resour. Manag. 27, 3555, 2013.

52. SHIVHARE V., GUPTA C., MALLICK J., SINGH C.K. Geospatial Modelling for Sub-Watershed Prioritization in Western Himalayan Basin Using Morphometric Parameters. Nat. Hazards, 1, 2021.

53. HASANEAN H., ALMAZROUI M. Rainfall: Features and Variations over Saudi Arabia, a Review. Climate 3, 578, 2015. 
54. KOPPEN W. DAS Das Geographische System Der Klimat. Handb. der klimatologie, 46, 1936.

55. AL-JERASH M.A. Climatic Subdivisions in Saudi Arabia: An Application of Principal Component Analysis. J. Climatol. 5, 307, 1985.

56. AL-TAHER A.A. Drought and Human Adjustment in Saudi Arabia. GeoJournal 33, 411, 1994.

57. SUBYANI A.M., AL-MODAYAN A.A., AL-AHMADI F.S. Topographic, seasonal and aridity influences on rainfall variability in western Saudi Arabia; 18, 2010.

58. MALLICK J. Geospatial-Based Soil Variability and Hydrological Zones of Abha Semi-Arid Mountainous Watershed, Saudi Arabia. Arab. J. Geosci. 9, 281, 2016.

59. CHORLEY R., HORTON R.E. 1945: Erosional Development of Streams and Their Drainage Basins: Hydrophysical Approach to Quantitative Morphology. Bulletin of the Geological Society of America 56, 2 75-370. Prog. Phys. Geogr. 19, 533, 1995, doi:10.1177/030913339501900406.

60. MAHALA A. The Significance of Morphometric Analysis to Understand the Hydrological and Morphological Characteristics in Two Different Morpho-Climatic Settings. Appl. Water Sci. 10, 1, 2020.

61. ARULBALAJI P., PADMALAL D. Sub-Watershed Prioritization Based on Drainage Morphometric Analysis: A Case Study of Cauvery River Basin in South India. J. Geol. Soc. India, 95, 25, 2020.

62. KANT S., MESHRAM S., DOHARE R., SINGH S. Morphometric Analysis of Sonar Sub-Basin Using SRTM Data and Geographical Information System (GIS). African J. Agric. Res. 10, 1401, 2015.

63. ARULBALAJI P., GURUGNANAM B. Geospatial Tool-Based Morphometric Analysis Using SRTM Data in Sarabanga Watershed, Cauvery River, Salem District, Tamil Nadu, India. Appl. Water Sci. 7, 3875, 2017.

64. MORISAWA M.E. Quantitative Geomorphology of Some Watersheds in the Appalachian Plateau. Geol. Soc. Am. Bull. 73, 1025, 1962.

65. SREEDEVI P.D., SUBRAHMANYAM K., AHMED S. The Significance of Morphometric Analysis for Obtaining Groundwater Potential Zones in a Structurally Controlled Terrain. Environ. Geol. 47, 412, 2005.

66. SAKTHIVEL R., RAJ N.J., SIVASANKAR V., AKHILA P., OMINE K. Geo-Spatial Technique-Based Approach on Drainage Morphometric Analysis at Kalrayan Hills, Tamil Nadu, India. Appl. Water Sci. 9, 24, 2019.

67. SCHUMM S.A. Evolution of Drainage Systems and Slopes in Badlands at Perth Amboy, New Jersey. Geol. Soc. Am. Bull. 67, 597, 1956.

68. VERSTAPPEN H. The Applied Geomorphology, International Institute for Aerial Survey and Earth Science (ITC), Enschede. The Netherlands 1983.

69. PANDE C.B., MOHARIR K. GIS Based Quantitative Morphometric Analysis and Its Consequences: A Case Study from Shanur River Basin, Maharashtra India. Appl. Water Sci. 7, 861, 2017.

70. HAJAM R.A., HAMID A., BHAT S. Application of Morphometric Analysis for Geo-Hydrological Studies Using Geo-Spatial Technology - a Case Study of Vishav Drainage Basin. Hydrol. Curr. Res. 4, 1, 2013.

71. RAMAIAH S.N., GOPALAKRISHNA G.S., VITTALA S.S., NAJEEB K.M. Morphometric Analysis of SubBasins in and around Malur Taluk, Kolar District, Karnataka Using Remote Sensing and GIS Techniques. Nature, Environ. Pollut. Technol. 11, 89, 2012.
72. WAIKAR M.L., NILAWAR A.P. Morphometric Analysis of a Drainage Basin Using Geographical Information System: A Case Study. Int J Multidiscip Curr Res, 2, 179, 2014.

73. PARETA K., PARETA U. Quantitative Morphometric Analysis of a Watershed of Yamuna Basin, India Using ASTER (DEM) Data and GIS. Int. J. Geomatics Geosci. 2, 248, 2011.

74. PARETA K., PARETA U. Quantitative Geomorphological Analysis of a Watershed of Ravi River Basin, HP India. Int J Remote Sens GIS, 1, 41, 2012.

75. KUMAR N. Morphometric Analysis of River Catchments Using Remote Sensing and GIS (a Case Study of the Sukri River, Rajasthan). Int. J. Sci. Res. Publ. 3, 1, 2013.

76. NAUTIYAL M.D. Morphometric Analysis of a Drainage Basin Using Aerial Photographs: A Case Study of Khairkuli Basin, District Dehradun, UP. J. Indian Soc. Remote Sens. 22, 251, 1994.

77. MORISAWA M. Rivers: Form and Process. Geomorphol. texts 1985.

78. SCHUMM S.A. The Relation of Drainage Basin Relief to Sediment Loss. Int. Assoc. Sci. Hydrol. 36, 216, 1954.

79. PADMAJA R.G. Some Morphometric Techniques with Relation to Discharge of Musi Basin. Andhra Pradesh, p6 p18176, proc. Sump Morphol. Evol. Landforms, Dep. Geol. Univ. Delhi, New Delhi, 110, 1978.

80. THOMAS J., JOSEPH S., THRIVIKRAMAJI K.P. Morphometric Aspects of a Small Tropical Mountain River System, the Southern Western Ghats, India. Int. J. Digit. Earth, 3, 135, 2010.

81. ABDETA G.C., TESEMMA A.B., TURA A.L., ATLABACHEW G.H. Morphometric Analysis for Prioritizing Sub-Watersheds and Management Planning and Practices in Gidabo Basin, Southern Rift Valley of Ethiopia. Appl. Water Sci. 10, 1, 2020.

82. AREFIN R., MOHIR M.M.I., ALAM J. Watershed Prioritization for Soil and Water Conservation Aspect Using GIS and Remote Sensing: PCA-Based Approach at Northern Elevated Tract Bangladesh. Appl. Water Sci. 10, $1,2020$.

83. CHITRA C., ALAGURAJA P., GANESHKUMARI K., YUVARAJ D., MANIVEL M. Watershed Characteristics of Kundah Sub Basin Using Remote Sensing and GIS Techniques. Int. J. Geomatic. Geosci. 2, 311, 2011.

84. RADWAN F., ALAZBA A.A., MOSSAD A. Watershed Morphometric Analysis of Wadi Baish Dam Catchment Area Using Integrated GIS-Based Approach. Arab. J. Geosci. 10, 1, 2017.

85. AL-SAADY Y.I., AL-SUHAIL Q.A., AL-TAWASH B.S., OTHMAN A.A. Drainage Network Extraction and Morphometric Analysis Using Remote Sensing and GIS Mapping Techniques (Lesser Zab River Basin, Iraq and Iran). Environ. Earth Sci. 75, 1243, 2016.

86. COATES D.R. Quantitative Geomorphology of Small Drainage Basins of Southern Indiana. Tech. Rep. (Columbia Univ. Dep. Geol. 10, 1958.

87. PATTON P.C. Drainage Basin Morphometry and Floods. Flood Geomorphol. John Wiley Sons New York. 1988. p 51-64. 11 fig, 1 tab, 67 ref. 1988.

88. JAVED A., KHANDAY M.Y., RAIS S. Watershed Prioritization Using Morphometric and Land Use/Land Cover Parameters: A Remote Sensing and GIS Based Approach. J. Geol. Soc. India, 78, 63, 2011.

89. CHANDNIHA S.K., KANSAL M.L. Prioritization of Sub-Watersheds Based on Morphometric Analysis Using 
Geospatial Technique in Piperiya Watershed, India. Appl. Water Sci. 7, 329, 2017.

90. MUNDETIA N., SHARMA D., DUBEY S.K. Morphometric Assessment and Sub-Watershed Prioritization of Khari River Basin in Semi-Arid Region of Rajasthan, India. Arab. J. Geosci. 11, 1, 2018.

91. MALIK A., KUMAR A., KUSHWAHA D.P., KISI O., SALIH S.Q., AL-ANSARI N., YASEEN Z.M. The Implementation of a Hybrid Model for Hilly Sub-
Watershed Prioritization Using Morphometric Variables: Case Study in India. Water, 11, 1138, 2019.

92. GHOSH M., GOPE D. Hydro-Morphometric Characterization and Prioritization of Sub-Watersheds for Land and Water Resource Management Using Fuzzy Analytical Hierarchical Process (FAHP): A Case Study of Upper Rihand Watershed of Chhattisgarh State, India. Appl. Water Sci. 11, 1, 2021. 